\title{
The Roles of Amino Acids and Sugars in the Production of Volatile Materials in Microwave Heated Tobacco Dust Suspensions
}

by

W. M. Coleman, III, and T. A. Perfetti

R.J. Reynolds Tobacco Company

P. O. Box 1487

Winston-Salem, NC 27102-1487, USA

\section{SUMMARY}

For the first time, the role(s) of selected amino acids and sugars in the production of volatile compounds in microwave prepared heat treated tobacco suspensions (HTTS) has been unambiguously defined. The role can be expressed in two major reaction pathways: 1) Strecker degradation of amino acids and 2) amino acid/sugar Maillard-type reactions. The mechanism of the Strecker degradation was confirmed by the addition of selected ${ }^{13} \mathrm{C}$ - labeled amino acids to the reaction suspension. The addition of the amino acid resulted in a dramatic increase in the concentration of the specific, appropriate, low molecular weight Strecker aldehyde in the headspace above the reaction suspension. The mechanism of the amino acid/sugar Maillard-type reactions was substantiated by: 1) adding a wide array of amino acids to the suspension; 2) by employing ${ }^{15} \mathrm{~N}$-labeled amino acids; and 3) employing ${ }^{13} \mathrm{C}$-labeled sugars. Addition of amino acids to the suspension followed by heat treatment resulted in significant increases $(2 \times)$ in the concentration of volatile pyrazines relative to the control. Most amino acids significantly increased the concentration of headspace pyrazines. Reactivity differences, as a function of sugars, was also demonstrated. Analysis of the headspace above suspensions incorporating ${ }^{15} \mathrm{~N}$-labeled amino acids and ${ }^{13} \mathrm{C}$-labeled sugars revealed the ${ }^{15} \mathrm{~N}$ and ${ }^{13} \mathrm{C}$ atoms to have

been distributed throughout a wide array of volatile pyrazines. The distribution of the ${ }^{15} \mathrm{~N}$ atoms within the pyrazines was unique to the amino acid and the distribution of the ${ }^{13} \mathrm{C}$ atoms was linked to the type of sugar employed. These results have documented for the first time in a heat treated tobacco formulation the mechanisms of amino acids and sugars in the production of volatile compounds which have documented intense sensory characteristics.

\section{ZUSAMMENFASSUNG}

Zum ersten Mal wurde die Rolle ausgewählter Aminosäuren und Zucker bei der Bildung von flüchtigen Verbindungen in mikrowellenerhitzten Tabaksuspensionen (HTTS) eindeutig definiert. Dieser. Wirkungsmechanismus läßt sich durch zwei Hauptreaktionswege beschreiben: 1) Streckerabbau von Aminosäuren und 2) Aminosäuren/Zucker-Umsetzungen nach Maillard. Der Mechanismus des Streckerabbaus wurde durch den Zusatz ausgewählter ${ }^{13} \mathrm{C}$-markierter Aminosäuren zum Reaktionsgemisch bestätigt. Die Zugabe von Aminosäuren führte zu einem starken Anstieg der Konzentration entsprechender, spezifischer, niedermolekularer Streckeraldehyde in der Gasphase über der Reaktionssuspension. Der Mechanismus der Aminosäuren/Zucker-Umsetzungen wurde durch folgendes Vorgehen wahrscheinlich gemacht: 1) durch Zugabe verschiedener Aminosäuren zum Reaktionsgemisch; 2) durch Einsatz von ${ }^{15} \mathrm{~N}$-mar- 
kierten Aminosäuren; 3) durch Einsatz von ${ }^{13} \mathrm{C}$-markierten Zuckern. Der Zusatz von Aminosäuren zur Reaktionssuspension mit nachfolgender Wärmebehandlung führte zu einer signifikanten Erhöhung (zweifach) der Konzentration von Pyrazinen in der Gasphase im Vergleich zur Kontrolle. Die meisten Aminosäuren führten zu einer signifikanten Erhöhung der Konzentration der gasförmigen Pyrazine. Der Zusatz von verschiedenen Zuckern führte darüber hinaus zu Unterschieden in der Reaktivität. Die Analyse der Gasphase über dem mit ${ }^{15} \mathrm{~N}$ markierten Aminosäuren und ${ }^{13} \mathrm{C}$-markierten Zuckern versetzten Reaktionsgemisch ergab, daß die ${ }^{15} \mathrm{~N}$ - und ${ }^{13} \mathrm{C}$ Atome über eine Vielzahl flüchtiger Pyrazine verteilt waren. Die Verteilung des ${ }^{15} \mathrm{~N}$-Atoms bei den Pyrazinen war für jede Aminosäure charakteristisch und die Verteilung des ${ }^{13} \mathrm{C}$-Atoms war von dem jeweils verwendeten Zucker abhängig. Die Ergebnisse haben zum ersten Mal den Wirkungsmechanismus aufgezeigt, über den Aminosäuren und Zucker bei erhitzten Tabaksuspensionen zur Bildung von volatilen Verbindungen beitragen, welche starke sensorische Eigenschaften aufweisen.

\section{RESUME}

Le rôle que jouent les aminoacides et les sucres dans la production de composés volatils dans les suspensions de tabac chauffées dans un four à hyperfréquence (HTTS) a pour la première fois été clairement défini. Ce rôle est caractérisé par deux processus réactionnels principaux: 1) dégradation de Strecker des aminoacides et 2) transformations des aminoacides/sucres d'après Maillard. Le mécanisme de la dégradation de Strecker a été confirmé à l'aide de l'addition des aminoacides radio marqués au carbone ${ }^{13} \mathrm{C}$ à la suspension réactionnelle. Dans la phase gazeuse au-dessus de la suspension l'addition des aminoacides a mené à une forte augmentation des aldéhydes de Strecker spécifiques, conformes, de faible poid moléculaire. Le mécanisme de transformation aminoacides/sucres d'après Maillard a été démontré par le procédé suivant: 1) l'addition de divers aminoacides au mélange réactionnel; 2) l'emplois d'aminoacides radio marqués à l'azote ${ }^{15} \mathrm{~N}$; 3) l'emplois de sucres marqués au carbone ${ }^{13} \mathrm{C}$. L'addition d'aminoacides à la suspension avec traitement thermique consécutif a conduit a une augmentation significative (deux fois) de la concentration en pyrazines volatiles par rapport au contrôle. La plupart des aminoacides a mené à une augmentation significative de la concentration en pyrazines volatiles. En outre, les variations de réactivité en fonction de sucres ont été démontrées. L'analyse de la phase gazeuse au-dessus de la suspension a révélé que les atomes d'azote ${ }^{15} \mathrm{~N}$ et de carbone ${ }^{13} \mathrm{C}$ ont été distribués sur de nombreuses pyrazines volatiles. La distribution du radioazote ${ }^{15} \mathrm{~N}$ dans les pyrazines était caractéristique pour les aminoacides et la distribution du radiocarbone
${ }^{13} \mathrm{C}$ a varié en fonction du sucre utilisé. Ces résultats ont pour la première fois démontré le processus réactionnel provoqué par les aminoacides et les sucres qui conduit dans les suspensions de tabac chauffées à la production de composés volatils avec des caractéristiques sensorielles intenses.

\section{INTRODUCTION}

The term "Maillard reaction" is used to characterize, among the great number of reactions occurring during the heating of natural products, a group of chemical reactions involving the amino and carbonyl functions present in natural products, leading to browning and flavor production (1). The principal reaction steps in the Maillard reaction were described by HODGE in 1953 (2). The first steps of the reaction involve the addition of the carbonyl group of the open-chain form of a reducing sugar to the primary amino group of an amino acid, peptide of other nitrogen containing compound. Fragmentation of this and other intermediates by a wide array of pathways yields a complex mixture of volatile, semivolatile and non-volatile compounds, including but not limited to aldehydes, ketones, pyrazines and pyridines. One such pathway, known as the Strecker degradation, involves the oxidative deamination and decarboxylation of an alphaamino acid in the presence of a dicarbonyl compound. The products from this reaction are an aldehyde containing one less carbon than the original amino acid and an $\alpha$ amino ketone (3). Thus, amino acids have been clearly shown to play a meaningful role in the synthesis of volatile and semivolatile material when reacted with sugars.

Under sugar-amino acid reaction conditions, it is often difficult to distinguish Strecker degradation products from other reactions and estimation of the aldehydes produced may be confused by carbonyl compounds formed by ancillary reactions such as sugar thermal degradation $(4,5)$. However, in a number of investigations it has been demonstrated that over $90 \%$ of the aldehydes produced in sugar-amino acids reactions come from the amino acid. The significant volatile aldehydes that result from sugar thermal degradation are furfural and substituted furfural derivatives (5).

The volatile aldehydes resulting from the Strecker degradation reaction are listed in Table 1 . The sensory characteristics of these aldehydes vary considerably; some are described as pungent (6).

Across a wide series of studies, a majority of the array of aldehydes presented in Table 1 have consistently appeared in the headspace of heat treated tobacco materials. These aldehydes have also appeared in large quantities in the headspace above other heat treated natural products $(7-12)$. Thus, due to: 1$)$ their ubiquitous nature across a 
Table 1.

Amino acids and their corresponding strecker aldehydes.

\begin{tabular}{ll}
\hline \multicolumn{1}{c}{ Amino acids } & \multicolumn{1}{c}{ Aldehydes } \\
\hline & \\
Glycine & Formaldehyde \\
$\alpha$-Alanine & Acetaldehyde \\
$\alpha$-Aminobutyric acid & Propanal \\
Valine & 2-Methylpropanal \\
Leucine & 3-Methylbutanal \\
Isoleucine & 2-Methylbutanal \\
Serine & 2-Hydroxyethanal \\
Threonine & 2-Hydroxypropanal \\
Methionine & 3-Methylthiopropanal \\
Phenylglycine & Benzaldehyde \\
Phenylalanine & Phenylacetaldehyde \\
Tyrosine & 2-( $p$-Hydroxyphenyl)ethanal \\
& \\
\hline
\end{tabular}

extensive array of tobacco materials, and 2) the strength of their sensory effects, it was important to define the role of amino acids in the production of these aldehydes in a tobacco matrix. Furthermore, it was also important to determine if the levels of selected volatile pyrazines were influenced by the presence of increased levels of selected amino acids. Presumably, the nitrogen from the amino acid would find its way into the pyrazines following established pathways (13). Likewise, in earlier preliminary work in our laboratory with tobacco dust and amino acids, it was observed that the addition of the amino acids to the tobacco dust matrix resulted in increased levels of pyrazines and selected Strecker aldehydes, such as 3methylbutanal and 2-methylbutanal (14).

A very important effect of microwave heating of open systems relating to flavor and aroma production is the water vapor migration. Many flavoring substances are steam volatile and during microwave heating will evaporate with the water. If no barrier is present the flavor/aroma compounds are lost to the atmosphere (15). Likewise, in an open system, the temperature of the process is controlled mainly by the boiling point of the water, $100{ }^{\circ} \mathrm{C}$. Thus, optimum conditions favoring sugar/amine, Maillard, and sugar thermal degradation reactions may not be reached in a conventional microwave setting. Thus, many efforts in the area of food production have focused on the addition of flavor supplements to microwave cooked foods.

Several comparisons exist covering the production of flavor compounds in open microwave and conventional cooking systems (15). In addition, characterization of model systems such as amino acids and reducing sugars have been performed on products made in open microwave systems (15). In some cases very similar products have been formed while in other cases meaningful differences have been detected between conventional and microwave produced materials, particularly in foods. However, with the advent of microwave transparentsealable containers, conditions necessary for the acceleration of chemical reactions have been possible. For example, on a more fundamental level, single-step organic reactions, such as esterification, hydrolysis, cyclization and Diels-Alder type reactions, have been performed in the conventional reflux mode as well as in sealed microwave vessels $(16,17)$. These studies show there to be no fundamental differences between microwave and reflux methods of heating. The reactions proceed through the same mechanisms, to produce similar products, in comparable yields. However, if the microwave heating is done in a closed system, the rate of the microwave assisted reaction becomes faster, up to several hundred times. This rate increase is due to the superheating of the solvent system.

Very recently a review of the development of laboratory scale continuous and batch microwave reactors has been published (18). The capability of controlled heating under controlled pressure was described. Therefore, it occurred to us that production of Maillard reaction products in aqueous based tobacco formulations might be accelerated/controlled through the use of microwave technology on formulations enclosed in a sealed system.

Hence, to more fully and clearly define the role of amino acids and other reagents in the production of volatiles in heat treated tobacco materials, a series of experiments was designed. These experiments involved the use of a newly developed microwave heat treatment process for the preparation of aqueous tobacco dust heat treated tobacco suspensions with and without the addition of selected amino acids and sugars. The resultant very aromatic/ flavorful suspensions were examined closely by means of a purge and trap ( $\mathrm{P} \& \mathrm{~T}$ )/ gas chromatography (GC)/ selected ion monitoring (SIM)-mass selective detection (MSD)/ flame ionization detection (FID) approach for the presence of selected pyrazines, sugar degradation products and Strecker aldehydes.

\section{EXPERIMENTAL}

\section{Sample preparation}

To generate the selected heat treated materials, a microwave based heat treatment protocol was employed (15). To $3.0 \mathrm{~g}$ of tobacco dust was added $27 \mathrm{~g}$ of water and $0.03 \mathrm{~g}$ of the selected amino acid and/or $0.0225 \mathrm{~g}$ of the selected sugar, if required. The suspension was microwave heated at $175^{\circ} \mathrm{C}$ in a sealed microwave-permeable vessel 
for 30 minutes. The special vessel was obtained from CEM Corporation and assembled closely following the manufacturer's instructions. A ramp time of 10 minutes was used to bring the suspension from room temperature to $175^{\circ} \mathrm{C}$. All microwave reactions were performed in a CEM Corporation, Model MES-1000 system. The microwave power was set at maximum, $950 \pm 50$ watts at a frequency of $2450 \mathrm{MHz}$. A turntable located inside the oven cycled back and forth during the run to insure even adsorption of the microwave energy.

Microwave heat treated samples were either analyzed immediately after returning to room temperature or stored in a freezer $\left(-18^{\circ} \mathrm{C}\right)$ prior to analysis.

\section{Headspace measurements}

The headspace measurements were conducted as previously described (9) with only minor changes. In these experiments $1 \mathrm{~mL}$ of the heat treated suspension was added to a $5 \mathrm{~mL}$ purge tube followed by the addition of $1 \mathrm{~mL}$ of a deionized water solution containing cyclohexanone at a known concentration, $\sim 20 \mathrm{ng} / \mu \mathrm{L}$. The response of the internal standard cyclohexanone was used to calculate the amount of volatile material produced as a result of the heat treatment reactions. The suspensions were purged with dry $\mathrm{He}$ for 20 minutes at $70^{\circ} \mathrm{C}$.

For this work, the mass spectrometer was sometimes operated in the selected ion mode to detect the presence of selected volatile pyrazines. For example, the selected ions, $\mathrm{m} / \mathrm{z}$, employed for the pyrazines were as follows: pyrazine, 80, 81, 82; methylpyrazine, 94, 95, 96; $\mathrm{C}_{2}$ pyrazines, 107, 108, 109, 110; $\mathrm{C}_{3}$ pyrazines, 121,122 , 123,124 ; and $\mathrm{C}_{4}$ pyrazines, $135,136,137,138$. The terms $\mathrm{C}_{2}, \mathrm{C}_{3}$, and $\mathrm{C}_{4}$ pyrazines are used to denote pyrazines having 2, 3, and 4, carbons attached, respectively. For example, $\mathrm{C}_{2}$ pyrazines would refer to ethylpyrazine and all of the dimethylpyrazine isomers.

\section{Reagents}

The ${ }^{13} \mathrm{C}$-labeled and ${ }^{15} \mathrm{~N}$-labeled amino acids and ${ }^{13} \mathrm{C}$ labeled sugars were obtained from Cambridge Isotope Labs, Andover, MA, USA, and used as received.

\section{RESULTS AND DISCUSSION}

\section{Strecker aldehydes}

Tables 2 and $2 a$ contain a list of the major volatile components found in the headspace above a series of microwave heat treated tobacco dust suspensions with and without added amino acids. If Strecker degradation were a path- way in the microwave heat treated tobacco suspensions, then significant increases should be found in the appropriate Strecker aldehydes associated with the specific amino acid. The data in Tables 2 and 2a indicate that this was the case. For example, upon addition of valine, a dramatic increase of the comparable Strecker aldehyde, 2-methylpropanal, was evident, when compared to the Strecker aldehyde level in the control reaction, containing no added amino acid. Likewise, dramatic increases in 3methylbutanal, 2-methylbutanal, benzaldehyde and phenylacetaldehyde were observed for heat treated suspensions wherein the amino acids leucine, isoleucine, phenylglycine, and phenylalanine were added, respectively. It was obvious that increases in benzaldehyde and phenylacetaldehyde do not arise through any known sugar reaction, especially thermal degradation wherein furfurals are known to be dominate. These increases in Strecker aldehyde concentrations resulted in a dramatic increase in the amount of volatile material detected in the headspace above the microwave heat treated tobacco dust suspension formulations (Figure 1). Use of the two optical isomers of phenylglycine produced no meaningful changes in the profiles of the volatile materials (Table 2). This was somewhat expected in light of the fact that the mechanisms established in the literature for model systems would not implicate stereochemical considerations.

To more clearly and directly establish the link between the addition of selected amino acids and the presence of Strecker aldehydes, a selected number of ${ }^{13} \mathrm{C}$-labeled amino acids (valine, isoleucine, and phenylalanine) were individually reacted with the tobacco dust. Since the amino acids were uniformly ${ }^{13} \mathrm{C}$-labeled, then the peaks attributable to their Strecker aldehydes should have mass spectra consistent with the uniformly ${ }^{13} \mathrm{C}$-labeled aldehydes. For example, the mass spectrum of naturally abundant 2-methylpropanal reveals an ion at $\mathrm{m} / \mathrm{z}=72$, assignable to the molecular ion. If the 2-methylpropanal results from uniformly ${ }^{13} \mathrm{C}$-labeled valine, then the molecular ion should increase by $4 \mathrm{~m} / \mathrm{z}$ units to yield a new $\mathrm{m} / \mathrm{z}=76$. Examination of the mass spectrum of the 2 methylpropanal in the headspace above the reaction containing uniformly ${ }^{13} \mathrm{C}$-labeled valine revealed the mass spectrum to contain a parent ion at $\mathrm{m} / \mathrm{z}=76$, confirming valine as the source of the 2-methylpropanal (Figure 2). Identical trends in appropriate $\mathrm{m} / \mathrm{z}$ increases were noted for both the uniformly ${ }^{13} \mathrm{C}$-labeled isoleucine and phenylalanine experiments, i. e., the parent ions in mass spectra of 3-methylbutanal and benzeneacetaldehyde in the headspace above reactions containing uniformly ${ }^{13} \mathrm{C}$-labeled leucine and phenylalanine were consistent with molecules containing all ${ }^{13} \mathrm{C}$ atoms. Thus, for the first time, a direct link between the presence of Strecker aldehydes and precursor free amino acids has been established in heat treated tobacco materials. 


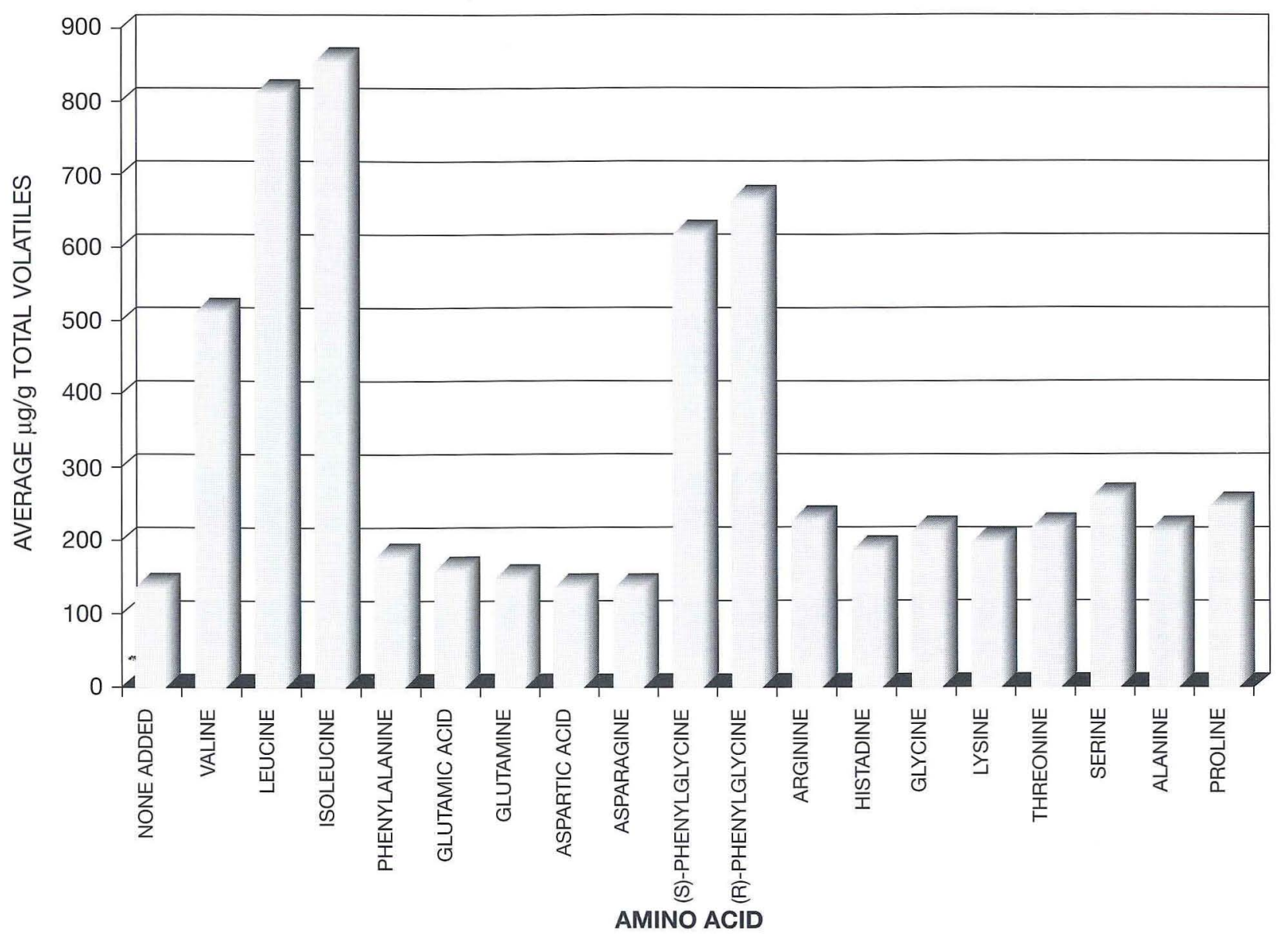

Figure 1.

Yield of total volatiles in the headspace above microwave HTTS formulations containing amino acids.

Therefore, under microwave heat treatment of aqueous suspensions, the free amino acids native to the tobacco dust are reacting with carbonyl containing species to yield the predicted Strecker aldehydes. Since the same types of volatile materials have been found in the headspace of other natural systems, it seems reasonable to now conclude that the same type of reaction(s) are occurring during the heat treatment of tobacco. Thus, the Strecker reaction pathway involving amino acids and sugar derived carbonyl compounds, previously demonstrated to occur in model reactions and other natural products, has been shown unambiguously to occur in tobacco as well.

\section{Pyrazine formation: source of $N$}

In addition to those amino acids capable of yielding Strecker aldehydes, several other amino acids were added to the array in an attempt to discover if the amino acids could be tied to the production of increased pyrazine levels, through the Maillard reactions $(13,16)$. The data in Tables 2 and 2 a would strongly indicate that the levels of pyrazines increased relative to the control when some of the amino acids were added to the formulation. An increase in the amounts of volatile pyrazines was not demonstrated by all of the amino acids. Of the 18 amino acids examined, all resulted in an increase in the amount of volatile pyrazines (Table 3 ). In some of the cases such as serine, valine and alanine, the amount of volatile pyrazines increased significantly relative to the control containing no added amino acids.

The question still lingers as to the exact contribution of amino acid to the nitrogen content in the volatile pyrazines. In other words, what is the extent of amino acid participation in the synthesis of pyrazines in a tobacco matrix? To gain a better perspective on this issue, a somewhat limited series of ${ }^{15} \mathrm{~N}$-amino acids were employed as added reagents to microwave prepared formulations in the same manner as described earlier for the unlabeled amino acids. ${ }^{14} \mathrm{~N}$ is the most abundant isotope comprising approximately $99.6 \%$ of all nitrogen atoms. Thus, use of ${ }^{15} \mathrm{~N}$ isotopes is a very acceptable way to assess nitrogen incorporation into synthesized molecules due to relatively simple increases in molecular weight. 


\begin{tabular}{|c|c|c|c|c|c|c|}
\hline & 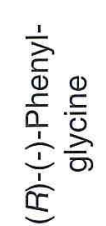 & 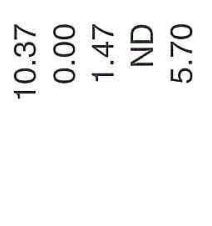 & 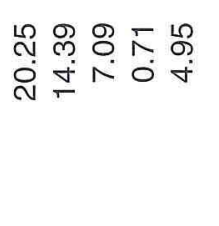 & 㖞 & 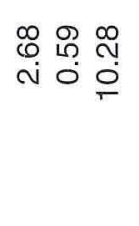 & 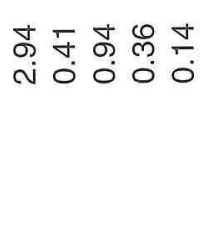 \\
\hline 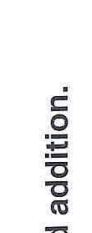 & 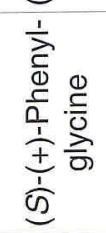 & 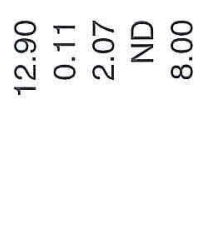 & 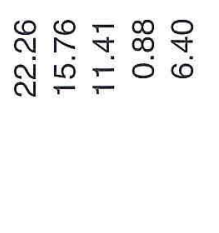 & 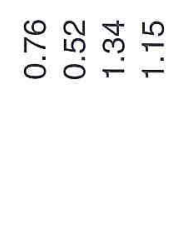 & 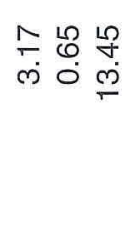 & 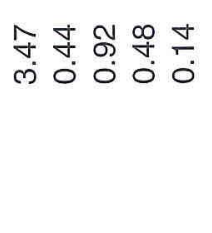 \\
\hline 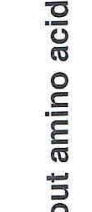 & 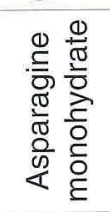 & 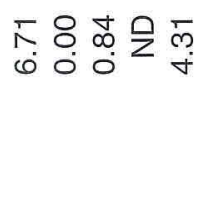 & 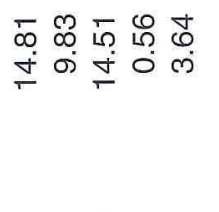 & 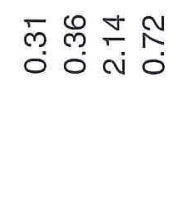 & \begin{tabular}{lll}
$\hat{N}$ & \multicolumn{1}{c}{$c$} & 0 \\
& 0 & 0 \\
0 & 0 & 0
\end{tabular} & 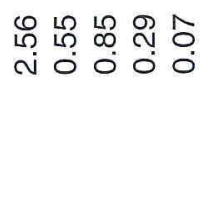 \\
\hline 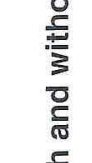 & 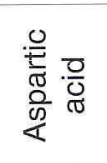 & 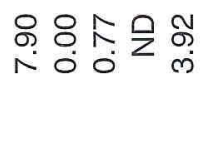 & 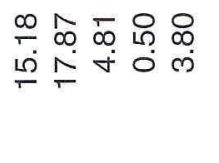 & 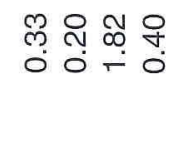 & 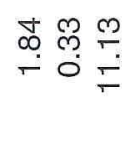 & 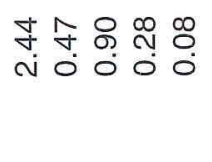 \\
\hline 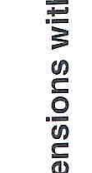 & 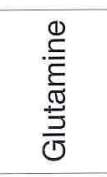 & 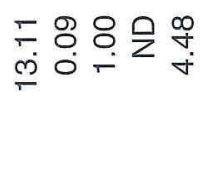 & 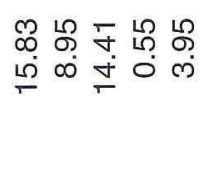 & 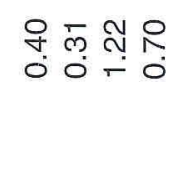 & 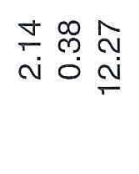 & 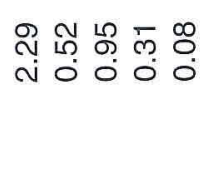 \\
\hline 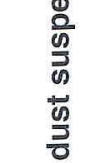 & $\begin{array}{l}\frac{0}{\bar{E}} \\
\frac{\pi}{\pi} \cdot \frac{0}{0} \\
\frac{\bar{J}}{0}\end{array}$ & 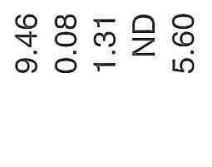 & 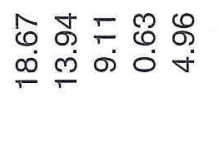 & 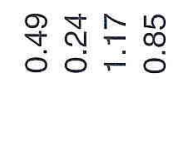 & 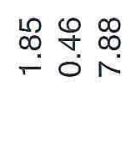 & 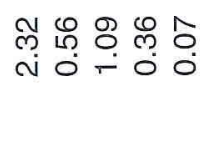 \\
\hline 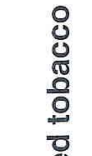 & 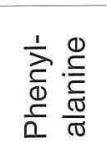 & 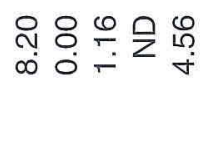 & 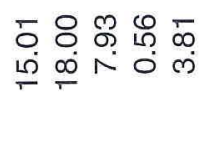 & 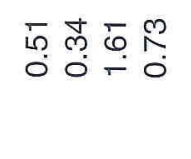 & 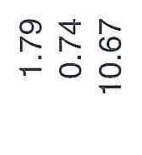 & 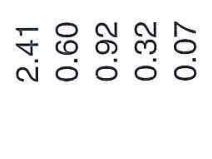 \\
\hline 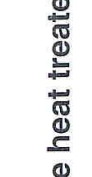 & 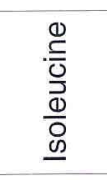 & 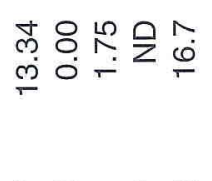 & 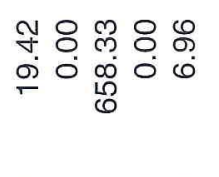 & 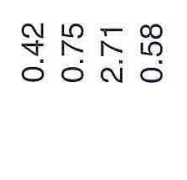 & 요용 & 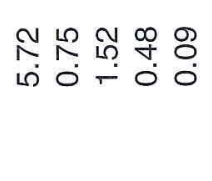 \\
\hline 苋 & 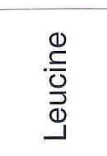 & $\begin{array}{l}\hat{N} 8 \\
0 \\
0\end{array}$ & 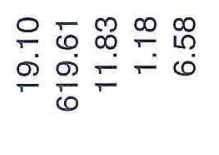 & 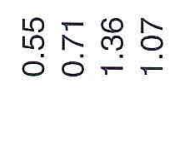 & 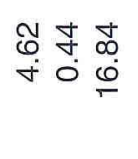 & 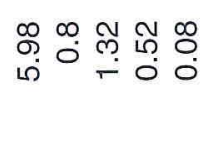 \\
\hline 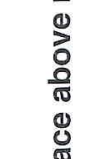 & 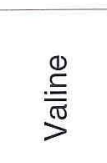 & 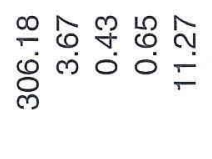 & 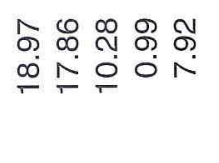 & 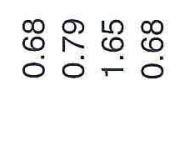 & 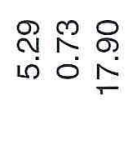 & 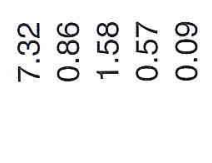 \\
\hline 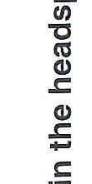 & 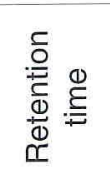 & 号 & 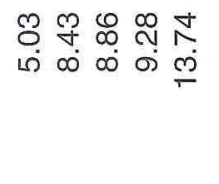 & 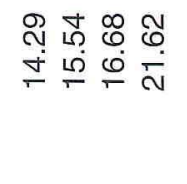 & 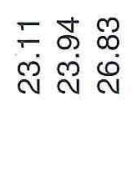 & 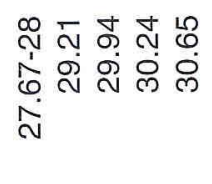 \\
\hline 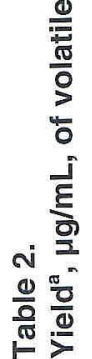 & 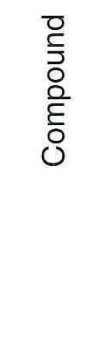 & 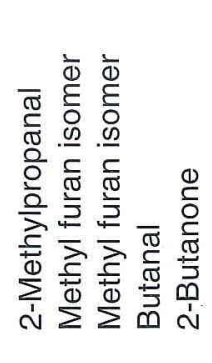 & 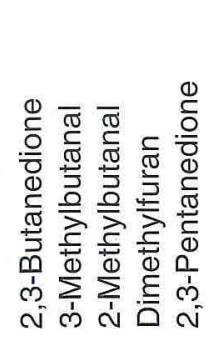 & 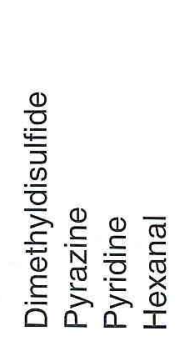 & 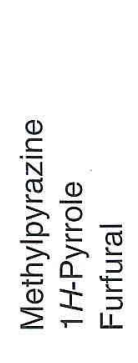 & 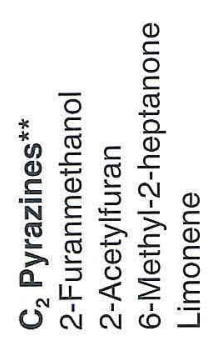 \\
\hline
\end{tabular}




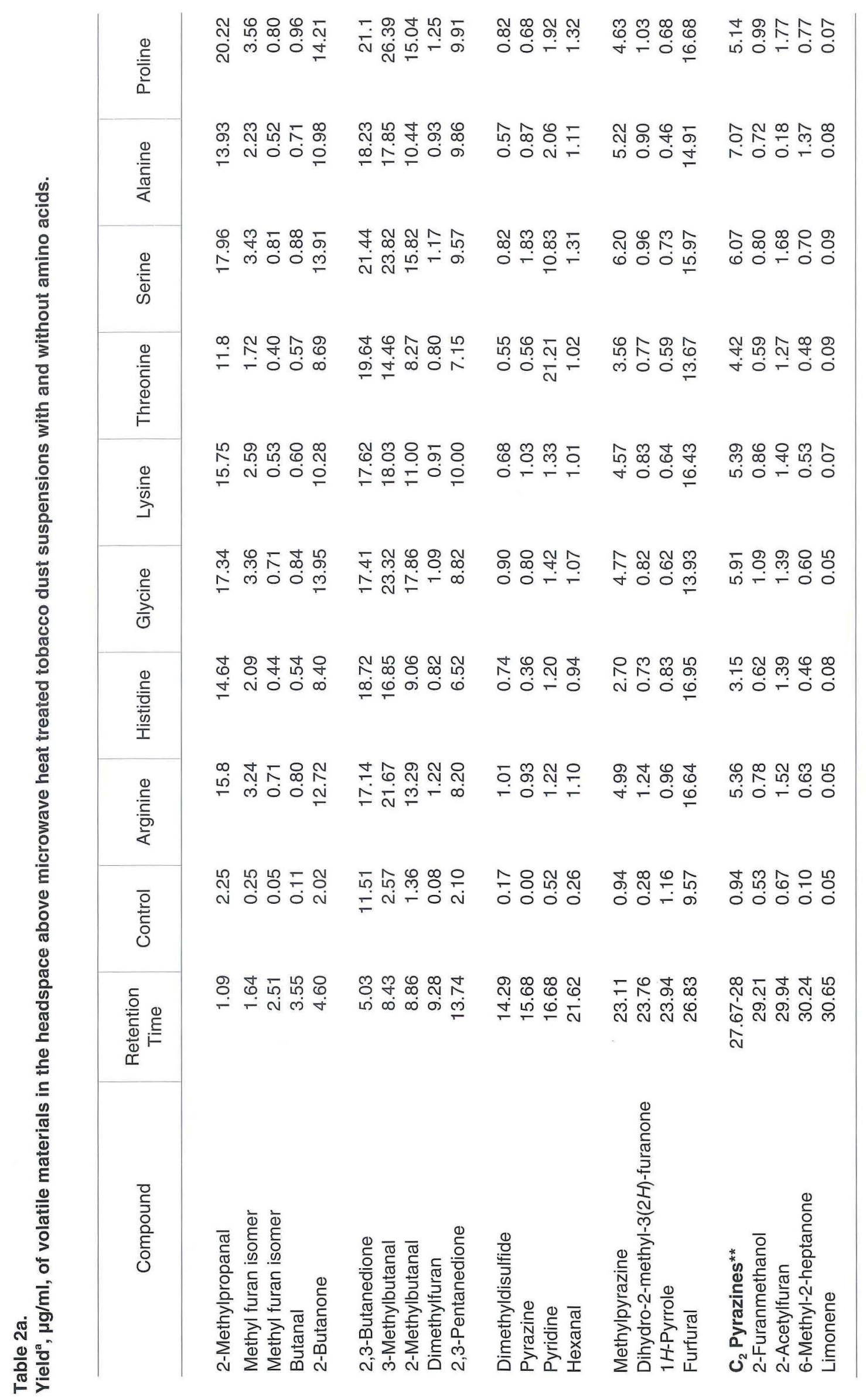




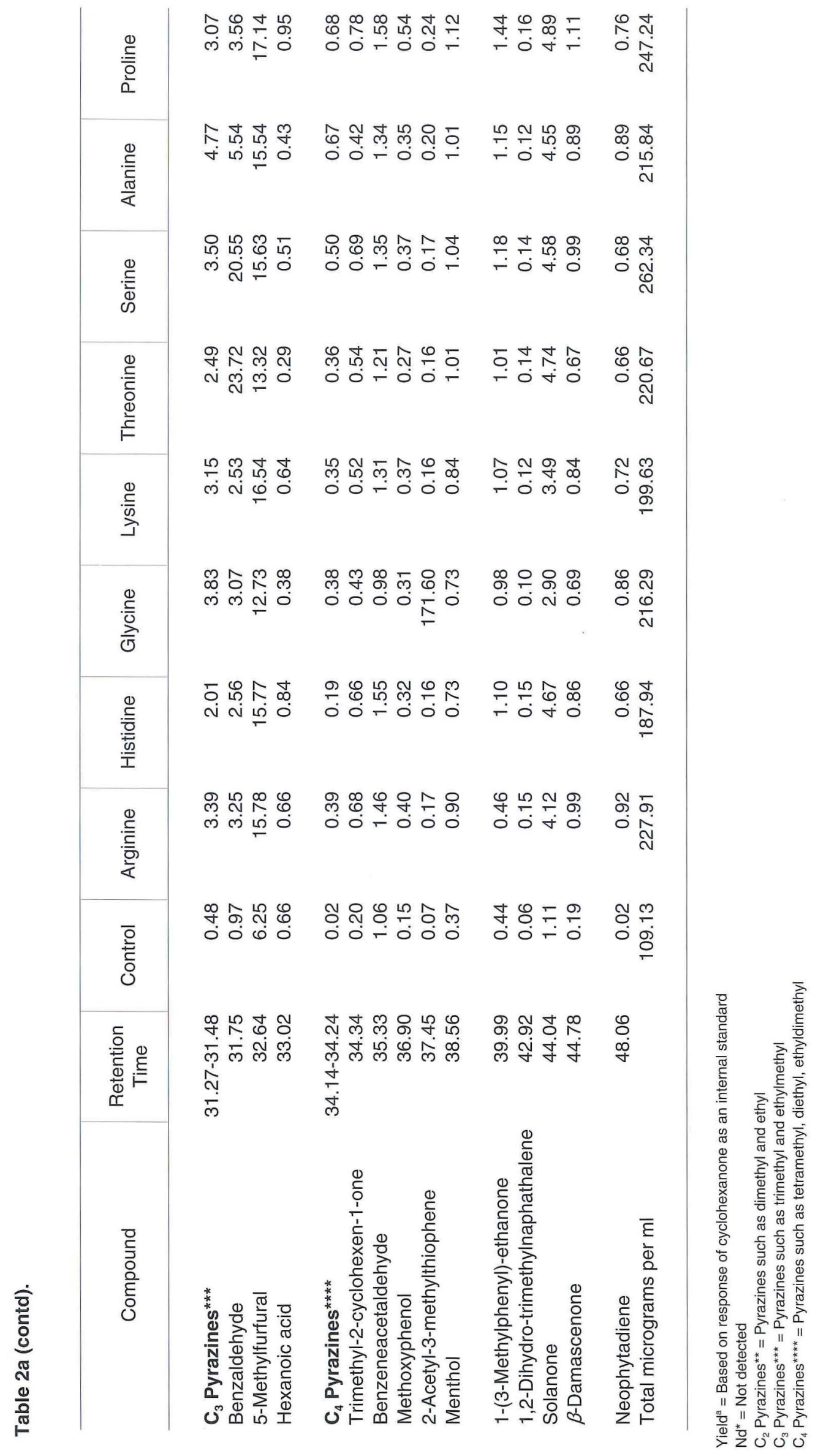




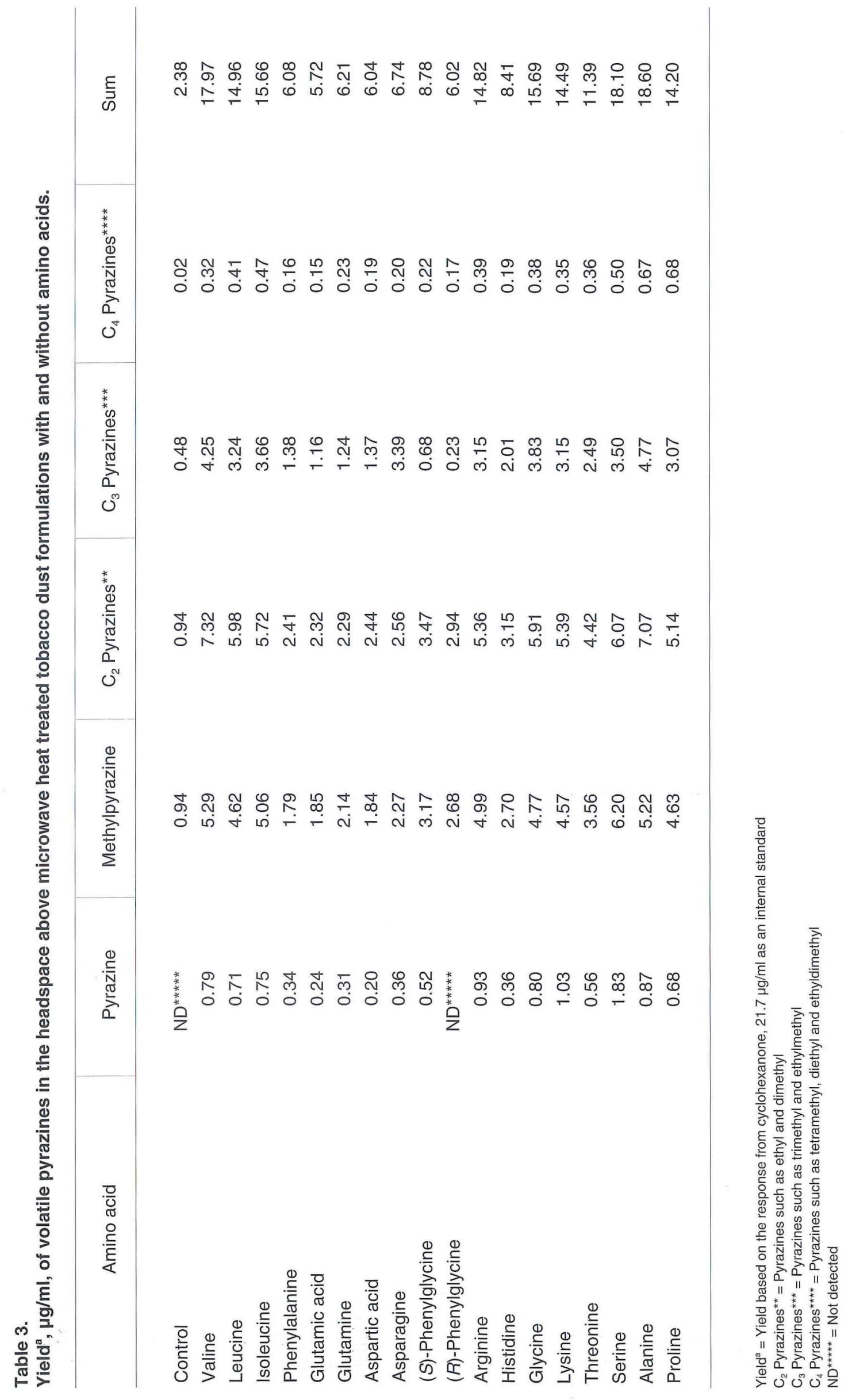




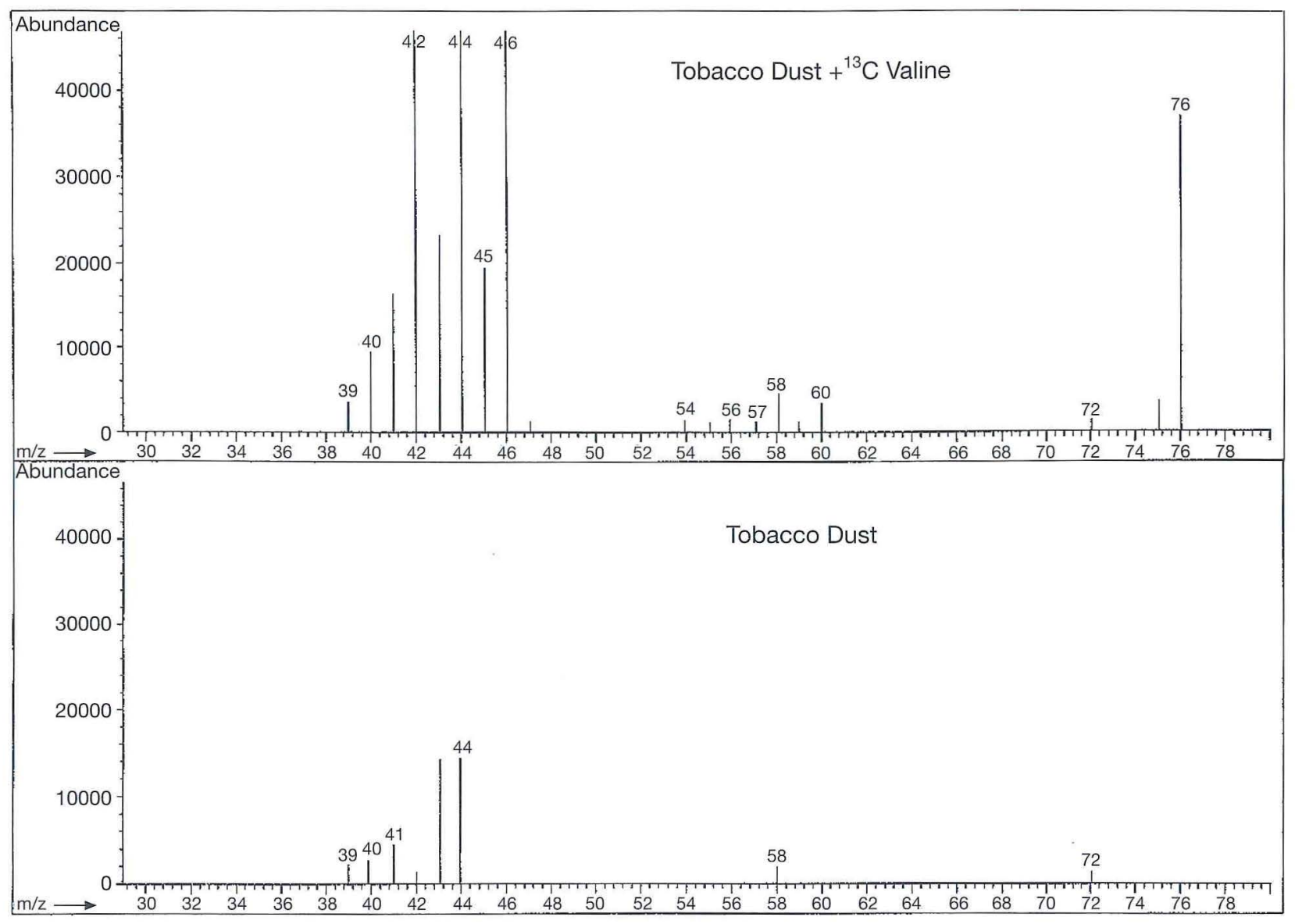

Figure 2.

Mass spectra of 2-methylpropanal.

Incorporation of one ${ }^{15} \mathrm{~N}$ atom versus one ${ }^{14} \mathrm{~N}$ into the pyrazine molecule leads to an increase in molecular weight of one unit while incorporation of two ${ }^{15} \mathrm{~N}$ atoms into a pyrazine would thus result in an increase in molecular weight of two over the naturally abundant ${ }^{14} \mathrm{~N}$ containing species. For example, the molecular weight of pyrazine and the most abundant ion in the electron impact mass spectrum of pyrazine is 80 due to the natural abundance of ${ }^{14} \mathrm{~N}$ being $99.6 \%$. Therefore, any contribution from a ${ }^{15} \mathrm{~N}$ atom in a naturally occurring arrangement is negligible. Such is observed in the mass spectrum of pyrazine. On the other hand, by purposely substituting one of the ${ }^{14} \mathrm{~N}$ atoms with ${ }^{15} \mathrm{~N}$, the molecular weight increases to 81 . Incorporation of a second ${ }^{15} \mathrm{~N}$ would thus yield a molecular weight of 82 . These identical arguments can be made for any other pyrazine. Therefore, since the molecular weights and resulting molecular ions of the pyrazines will change systematically upon incorporation of the ${ }^{15} \mathrm{~N}$, selected ion monitoring (SIM) mass selective detection (MSD) was employed to speciate the variety of pyrazine molecular structures produced in the presence of ${ }^{15} \mathrm{~N}$ amino acids.

Before proceeding to the data containing the results of the
SIM experiments, it is important to examine very closely the ion fragmentation pattern(s) for the naturally occurring pyrazines. The fragmentation pattern presented by each pyrazine molecule can and will influence the ability to define exactly the amount of ${ }^{15} \mathrm{~N}$ incorporated into the molecule. For pyrazine and methylpyrazine, the fragmentation patterns are relatively simple and, as such, clear interpretations of minimal ${ }^{15} \mathrm{~N}$ incorporation are possible. However, for example, the fragmentation pattern for one of the $\mathrm{C}_{3}$ pyrazines is much more complex and contains ions at $\mathrm{m} / \mathrm{z}=121,122,123$, and 124 . Contributions to the abundance of these ions can come from an array of several combinations of ${ }^{14} \mathrm{~N}$ and ${ }^{15} \mathrm{~N}$ in the $\mathrm{C}_{3}$ pyrazine, thereby complicating the clear assignment of an ion as arising from a molecule containing only ${ }^{15} \mathrm{~N}$. To illustrate this complicating effect, the ion at $\mathrm{m} / \mathrm{z}$ of 121 can only be due to the parent $\mathrm{C}_{3}$ pyrazine containing two ${ }^{14} \mathrm{~N}$ atoms $\left({ }^{14} \mathrm{~N}^{14} \mathrm{~N}\right)$ minus a proton. However, the ion at $\mathrm{m} / \mathrm{z}=122$ can arise from the parent ${ }^{14} \mathrm{~N}^{14} \mathrm{~N} \mathrm{C}_{3}$ pyrazine as well as a $\mathrm{C}_{3}{ }^{14} \mathrm{~N}{ }^{15} \mathrm{~N}$ pyrazine minus a proton. Furthermore, the ion at $\mathrm{m} / \mathrm{z}=123$ can arise from a ${ }^{14} \mathrm{~N}^{15} \mathrm{~N} \mathrm{C}_{3}$ pyrazine as well as a ${ }^{15} \mathrm{~N}^{15} \mathrm{~N} \mathrm{C}_{3}$ pyrazine minus a proton. Finally the ion at $\mathrm{m} / \mathrm{z}=124$ can only arise from a ${ }^{15} \mathrm{~N}^{15} \mathrm{~N} \mathrm{C}_{3}$ 
pyrazine. Similar arguments and approaches occur for the $\mathrm{C}_{2}$ and $\mathrm{C}_{4}$ pyrazines. By calculating the difference between the ${ }^{14} \mathrm{~N}^{1+} \mathrm{N}$ abundance in the naturally occurring formulation and the ${ }^{14} \mathrm{~N}^{14} \mathrm{~N}$ abundance in a ${ }^{15} \mathrm{~N}$ formulation, an additional percent contribution due to a molecule containing a ${ }^{15} \mathrm{~N}$ can be obtained. Thus, given the fragmentation patterns of the $\mathrm{C}_{2}, \mathrm{C}_{3}$ and $\mathrm{C}_{4}$ pyrazines, the minimal amount of ${ }^{15} \mathrm{~N}$ incorporation can be obtained. That is, only the ions known to positively arise from molecules containing ${ }^{15} \mathrm{~N}$ can be used to calculate the estimate. This estimate of minimal incorporation is gathered from the data on $\mathrm{C}_{2}$ pyrazines using the abundances at ions 107,109 , and 110 , from the $\mathrm{C}_{3}$ pyrazines by using ions at 121,123 and 124 , and from the $C_{4}$ pyrazines by using ions at 135,137 , and 138 . It is obvious that this estimate of ${ }^{15} \mathrm{~N}$ incorporation is minimal because at least one of the ions that possibly contains a ${ }^{15} \mathrm{~N}$ is not included in the abundance calculation.

To illustrate more clearly that the estimate of ${ }^{15} \mathrm{~N}$ incorporation is minimal, the following approach is provided for the $\mathrm{C}_{3}$ pyrazines:

1) the abundances in the naturally occurring formulation at ions 121, 122 were measured,

2) the abundances in $a^{15} \mathrm{~N}$ formulation at ions 121,123 , and 124 were measured,

3) the abundance in $a^{15} \mathrm{~N}$ formulation at ion 122 arising from the ${ }^{14} \mathrm{~N}^{14} \mathrm{~N} \mathrm{C}_{3}$ pyrazine was estimated by the following equation

$$
A^{122}(\text { calc. })=A^{121} \times\left(A^{* 122} / A^{* 121}\right)
$$

where $A=$ abundance in a ${ }^{15} \mathrm{~N}$ formulation; $A^{*}=$ abundance in naturally occurring formulation; and the superscript indicates the $\mathrm{m} / \mathrm{z}$ value;

4) the incorporation was thus calculated by the following equation

$$
A^{123}+A^{124} / A^{121}+A^{122}(\text { calc. }) A^{123}+A^{124}
$$

and finally, 5) because the abundance at ion 122 arising from the ${ }^{14} \mathrm{~N}^{15} \mathrm{~N} \mathrm{C}_{3}$ pyrazine minus one proton was not included in the calculation the estimates provided will be minimal in nature.

The data contained in Table 4 reveals clearly and unambiguously that ${ }^{15} \mathrm{~N}$ is being incorporated in all of the volatile pyrazines studied and that all of the amino acids studied participated in contributing their ${ }^{15} \mathrm{~N}$ to the quantified pyrazines. For example, the percent of ions containing ${ }^{15} \mathrm{~N}$ in a $\mathrm{C}_{2}$ pyrazine (retention time 27.7 minutes) from the naturally occurring formulation was approximately $7 \%$, while for the formulation containing $1 \%{ }^{15} \mathrm{~N}$-leucine the minimal ${ }^{15} \mathrm{~N}$ abundance for the same $\mathrm{C}_{2}$ pyrazine was approximately $92 \%$. Scanning the data in Table 4 reveals that the range of ${ }^{15} \mathrm{~N}$ incorporation spans from a low of $27 \%$ in pyrazine from the ${ }^{15} \mathrm{~N}$ - leucine experiment to a high of $95 \%$ in a $\mathrm{C}_{2}$ pyrazine in the same leucine experiment (Figure 3). It also appears that leucine and alanine are more effective in availing their $\mathrm{N}$ for the formation of pyrazines. This observation is consistent with the earlier findings, vide supra, in this report wherein not all of the amino acids participated to the same extent in the production of pyrazines.

Therefore, for the first time, under microwave heat treatment of aqueous tobacco suspensions, the free amino acids native to the tobacco dust are shown to react with carbonyl-containing species to yield the predicted volatile pyrazines. Since the same types of volatile materials have been found in the headspace of other natural systems, it seems reasonable that the same type of pyrazine formation reaction(s) are occurring during the heat treatment of tobacco. Thus, the pyrazine reaction pathway involving amino acids and sugar-derived carbonyl compounds, previously demonstrated to occur in model reactions and other natural products, has now been shown unambiguously to occur in tobacco as well.

\section{Pyrazine formation: source of carbon}

In earlier reports on model systems, it had been shown that the carbon source in the pyrazines originated from the sugar (16-25). However, no direct, unambiguous molecular-based link has been established between the presence of selected sugars and resultant volatile pyrazines in heat treated tobacco suspensions. It is relatively easy to envision a pyrazine molecule such as methylpyrazine as arising from one molecule, $\mathrm{A}$, containing 2 carbon atoms plus another molecule, $\mathrm{B}$, containing 3 carbon atoms (Figure 4). Should the source of these carbon containing pyrazine molecules arise for a precursor compound uniformly ${ }^{13} \mathrm{C}$-labeled, then the resulting methylpyrazine molecule could possess increases in mass of either 2 or 3 or $5 \mathrm{~m} / \mathrm{z}$ units depending on the extent of incorporation of the 2 and 3 carbon units. For example, naturally abundant methylpyrazine displays a molecular ion at $\mathrm{m} / \mathrm{z}$ $=94$. Should the methylpyrazine be produced from a carbon source uniformly ${ }^{13} \mathrm{C}$-labeled, then, increases in mass would display themselves in the form of the presence of ions at $\mathrm{m} / \mathrm{z}$ of either 96,97 or 99 corresponding to incorporation of a 2 or a 3 carbon unit as well as simultaneous incorporation of both the 2 and 3 carbon units. Similar arguments and deductions can be made for all of the pyrazines found in the headspace above the heat treated tobacco dust suspensions.

Thus, a variety of microwave heat treated tobacco dust suspension reactions were conducted employing a selected group of ${ }^{13} \mathrm{C}$-labeled sugar compounds (Table 5). The headspace above these reaction products was closely monitored for the presence of volatile pyrazines with particular attention being paid to the mass spectrum of 


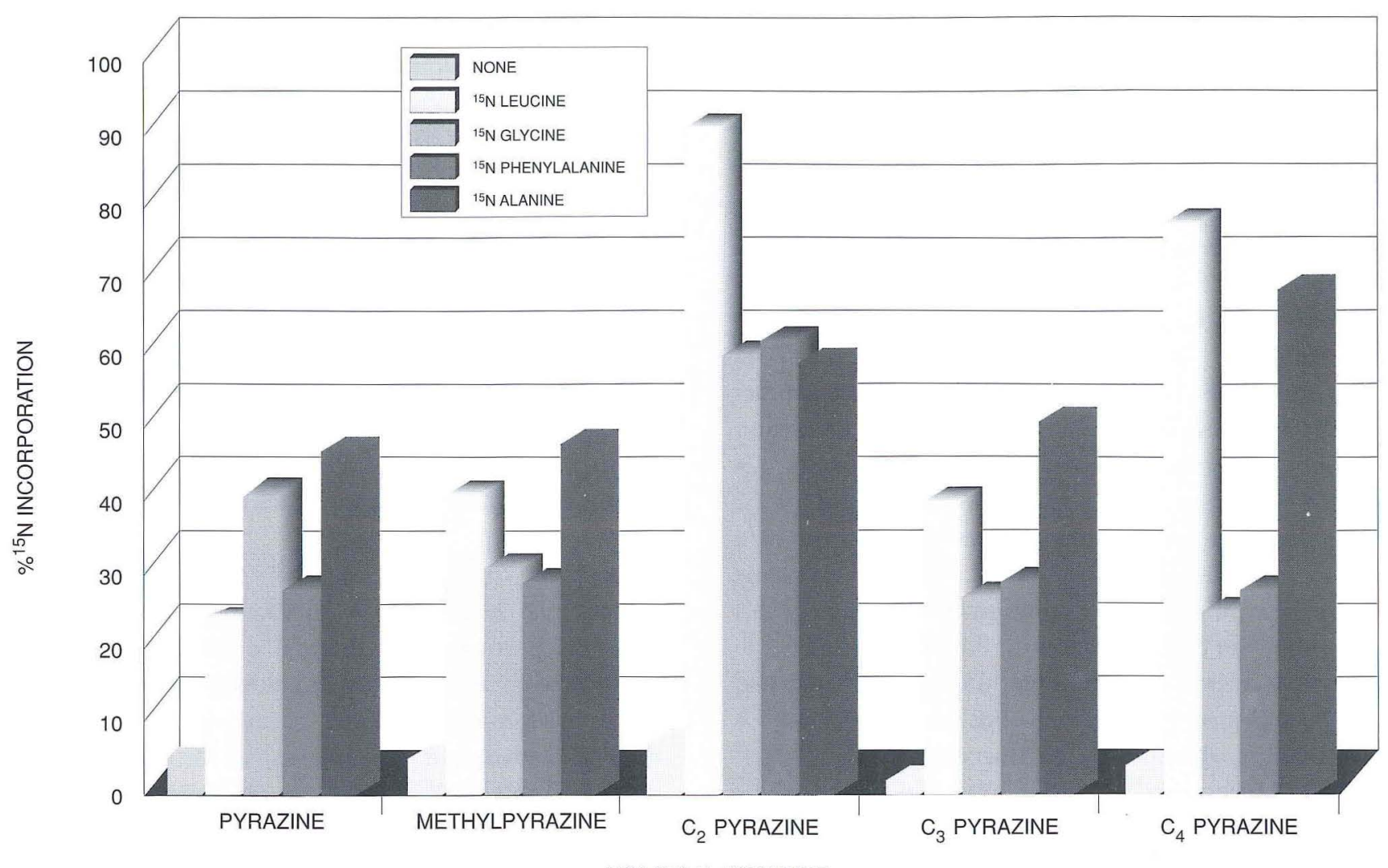

Figure 3.

Incorporation of ${ }^{15} \mathrm{~N}$ into volatile pyrazines.

each of the pyrazines. An examination of the mass spectral data set confirmed the anticipated incorporation of the ${ }^{13} \mathrm{C}$ label in a wide array of the volatile pyrazines (Table 5). Closer detailed examination disclosed some very informative results in terms of the mechanistic incorporation of the ${ }^{13} \mathrm{C}$-label as a function of sugar type and pyrazine structure. Four types of sugars, i.e., carbon sources, were used in the study: uniformly ${ }^{13} \mathrm{C}$-labeled glucose and fructose as well as ${ }^{13} \mathrm{C}$-labeled $\mathrm{C}_{1}$ and $\mathrm{C}_{2}$ fructose. The presence of naturally abundant fructose, glucose and sucrose in the tobacco dust tobacco material at $1.74 \%, 0.90 \%$, and $0.22 \%$, respectively, prevents the absolute assignment of the degree of ${ }^{13} \mathrm{C}$-label incorporation, but does not preclude the confirmation of ${ }^{13} \mathrm{C}$-label incorporation as a function of carbon source.

The ion abundances from pyrazine, $\mathrm{m} / \mathrm{z}=80$ (Table 5), strongly indicated that at least one 2 carbon unit from both uniformly ${ }^{13} \mathrm{C}$-labeled glucose and fructose was incorporated into the molecule due to the increase in abundance of the ions at $\mathrm{m} / \mathrm{z}=82$. It is clear that carbons 1 and 2 of the fructose molecule did not find their way into the pyrazine molecule, since no increase in the abundance of the ion at $\mathrm{m} / \mathrm{z} 81$ was observed in either case. The ion abundances from methylpyrazine indicated the incorporation of the ${ }^{13} \mathrm{C}$-label was significantly different than that observed for unsubstituted pyrazine. Both a 2 and a 3 carbon unit were incorporated into the methylpyrazine from uniformly ${ }^{13} \mathrm{C}$-labeled glucose. However, no simultaneous inclusion of both the 2 and 3 carbon unit appeared to occur. On the other hand, for fructose, there appeared to be a small amount of methylpyrazine that included both the 2 and 3 carbon units from the uniformly ${ }^{13} \mathrm{C}$-labeled fructose, $0.67 \%$. The $\mathrm{C}_{1}$ and $\mathrm{C}_{2}$-carbons from the ${ }^{13} \mathrm{C}_{1}$ and $13 \mathrm{C}_{2}$ fructose also found their way into the methylpyrazine molecule. This pathway seems very clear mechanistically in light of the literature (19-29).

A symmetrical molecule and as such 2,6-dimethylpyrazine offers a unique chance to examine the incorporation of either one or two 3 carbon units into the molecule. For glucose, it appears that only one side of the molecule incorporated the label, but for fructose there was sufficient evidence to indicate incorporation of two 3 carbon units into one pyrazine molecule. That is, notice the $0.7 \%$ abundance of $\mathrm{m} / \mathrm{z}=114$, corresponding to an<smiles>CC(=O)CN</smiles>

Figure 4.

Formation of methylpyrazine from two molecules. 
increase of $6 \mathrm{~m} / \mathrm{z}$ units from the parent ion at $\mathrm{m} / \mathrm{z}=108$. Both the $\mathrm{C}_{1}$ and $\mathrm{C}_{2}$-carbons from the ${ }^{13} \mathrm{C}_{1}$ and ${ }^{13} \mathrm{C}_{2}$ fructose were incorporated into a 2,6-dimethylpyrazine molecule. Furthermore, there was evidence that two ${ }^{13} \mathrm{C}_{1}$ and ${ }^{13} \mathrm{C}_{2}$ fructose carbons found their way into a 2,6dimethylpyrazine molecule. For ethylpyrazine, the evidence supported the incorporation of a 2 carbon or a 4 carbon unit into the molecule from uniformly ${ }^{13} \mathrm{C}$ labeled glucose but not both a 2 carbon or a 4 carbon unit simultaneously. However, for ethylpyrazine produced from uniformly ${ }^{13} \mathrm{C}$-labeled fructose the evidence appears to support in incorporation of a 2 carbon or a 4 carbon unit into the pyrazine molecule from the uniformly ${ }^{13} \mathrm{C}$ labeled fructose as well as simultaneous inclusion of a 2 carbon or a 4 carbon unit to yield a molecule with an $\mathrm{m} / \mathrm{z}$ $=113$. The ion abundances for 2,3-dimethylpyrazine indicated a different incorporation of the labels when compared with the abundances for ethylpyrazine and 2,6dimethylpyrazine. For example, uniformly ${ }^{13} \mathrm{C}$-labeled glucose appeared to incorporate both a 2 carbon and a 4 carbon units, as well as, simultaneous incorporation of both the 2 carbon and a 4 carbon units. Evidence for this conclusion rested with the $2.32 \%$ ion abundance of $\mathrm{m} / \mathrm{z}$ $=114$ corresponding to an increase of $6 \mathrm{~m} / \mathrm{z}$ units from the parent ion at $\mathrm{m} / \mathrm{z}=108$. Uniformly ${ }^{13} \mathrm{C}$-labeled fructose produced 2,3-dimethylpyrazine with a 2 carbon and a 4 carbon ${ }^{13} \mathrm{C}$ unit, but no evidence was found for the simultaneous incorporation of both. Both the $\mathrm{C}_{1}$ and $\mathrm{C}_{2}$-carbons from the ${ }^{13} \mathrm{C}_{1}$ and ${ }^{13} \mathrm{C}_{2}$ fructose were found in the 2,3-dimethylpyrazine molecule.

From the evidence gathered on the dimethyl- and ethylsubstituted pyrazines, it appears that the type of sugar employed can provide measurable influence on the distribution of the pyrazine substitutions. This is very significant because the odor threshold of various alkylpyrazines ranges over at least 4 orders of magnitude (29).

The carbons from both uniformly ${ }^{13} \mathrm{C}$-labeled glucose and fructose were incorporated into 2-ethyl-6-methylpyrazine in both 3 carbon and 4 carbon units as evidenced by increased ion abundances at $\mathrm{m} / \mathrm{z}=124$ and 125 . No evidence was suggested of simultaneous incorporation of both the 3 carbon and 4 carbon units for either the glucose or fructose reactions. The ${ }^{13} \mathrm{C}$-labeled $\mathrm{C}_{1}$ and $\mathrm{C}_{2}$ of fructose appeared in 2-ethyl-6-methylpyrazine. Interestingly enough, a very similar pattern of incorporation was discovered for 2-ethyl-5-methylpyrazine.

For 2-ethyl-3,6-dimethylpyrazine, the data indicated that for uniform ${ }^{13} \mathrm{C}$-labeled glucose and fructose that a 3 carbon unit was incorporated into the molecule. There was no indication with either sugar that a 5 carbon unit had been added to the molecule. Very strong evidence shows that both ${ }^{13} \mathrm{C}$-labeled $\mathrm{C}_{1}$ and $\mathrm{C}_{2}$ of fructose are incorporated into 2-ethyl-3,6-dimethylpyrazine.

A detailed analysis of the data in Table 5 revealed that the use of either uniformly ${ }^{13} \mathrm{C}$-labeled glucose or fructose produced similar amounts of incorporation of ${ }^{13} \mathrm{C}$ into the pyrazine structures. However, in some pyrazine structures, the carbons from glucose were more effectively incorporated, while in an equal number of other cases, the carbons from fructose were more effectively incorporated. At first glance, this is a somewhat unexpected result in light of the literature which indicates that fructose reacts more rapidly than glucose in the formation of pyrazines. On the other hand, there have been no reports of reactions of this type conducted within a sealed microwave reaction vessel at $175^{\circ} \mathrm{C}$ and $\sim 200$ psi. Such stringent reaction conditions may serve to eliminate any substantial differences in the reactivities of glucose and fructose.

In addition to the reactions of sugars with nitrogen sources, the sugars may at elevated temperatures and pressures participate in thermal degradation to yield substituted furans, ketones and aldehydes. Some of the more predominant volatile compounds from sugar thermal degradation, documented in the literature, are listed in Table 6. Also listed are the percent ion abundances for these selected compounds. The information in Table 6 confirmed that thermal degradation reaction pathway(s) occurs during the heat treatment of the tobacco dust suspensions for both glucose and fructose. For example, ions attributable to molecules containing uniform ${ }^{13} \mathrm{C}$-label were discovered for 2-butanone; 2,3butanedione; 2,3-pentanedione; furfural, and 5-methylfurfural, but surprisingly enough, not for the methylfurans. These aldehydes and ketones have been produced during the heat treatment of other natural products (10). Therefore, for the first time, sugar thermal degradation has been confirmed to occur during the heat treatment of a tobacco material.

\section{SUMMARY AND CONCLUSION}

The results reported herein have documented for the first time the mechanisms of amino acid/sugar reactions as major pathways in the production of volatile components in microwave heat treated tobacco suspensions. Two reaction pathways account for a large part of all the observed volatile components. These pathways, Strecker degradation and Maillard reactions, are very similar to those found in other natural products and model systems. Use of uniformly ${ }^{15} \mathrm{~N}$-labeled amino acids confirm that the nitrogen from the amino acids is distributed throughout the entire variety of volatile pyrazines. Use of uniformly ${ }^{13} \mathrm{C}$-labeled amino acids confirm that the source of selected aldehydes can be attributed to Strecker degradation. Use of uniformly ${ }^{13} \mathrm{C}$-labeled sugars confirm that the source of carbons in formation of selected volatile pyrazines can be attributed to the uniformly ${ }^{13} \mathrm{C}$-labeled 


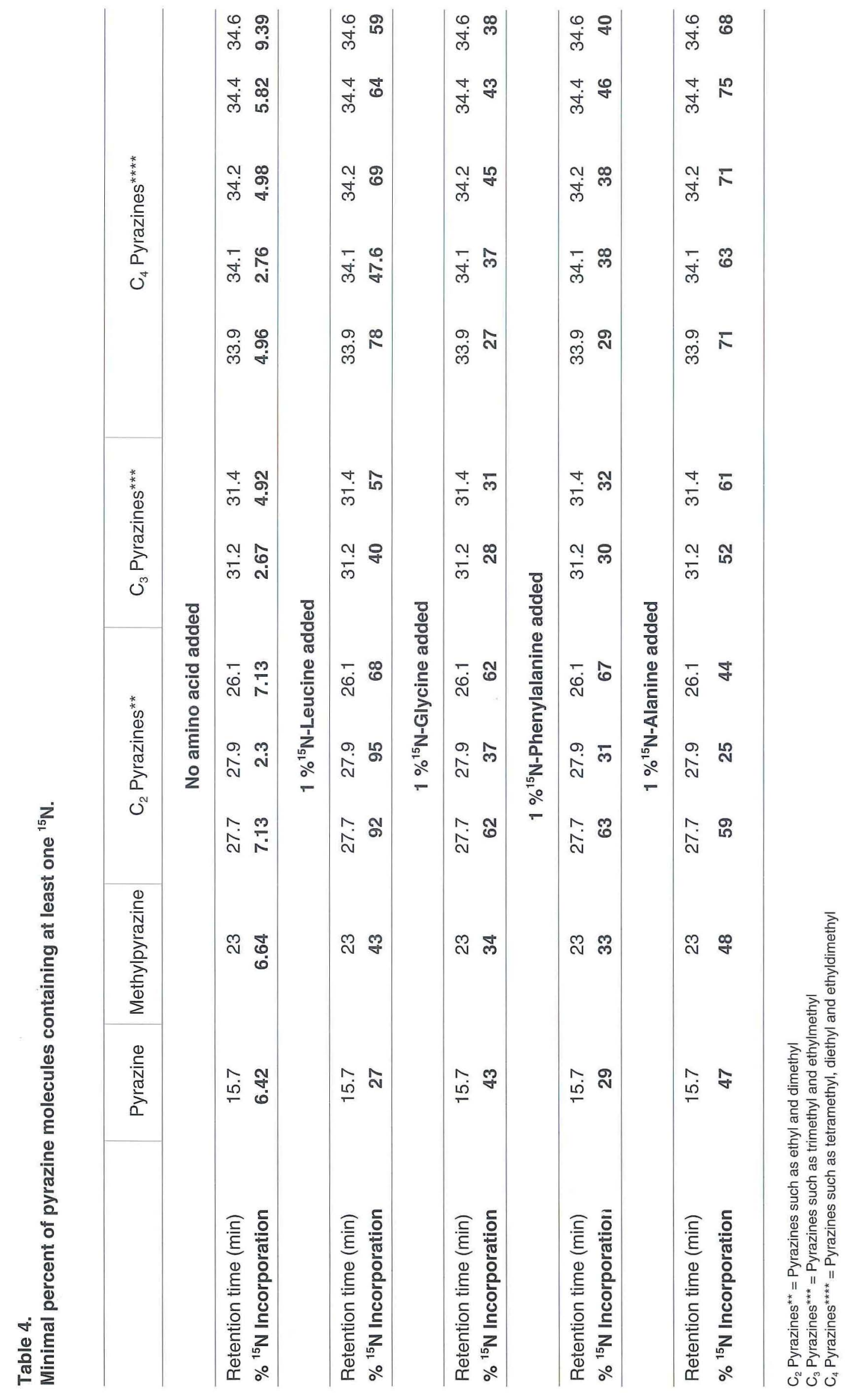


Table 5.

Percent ion abundances in pyrazines from microwave heat treated tobacco dust suspensions with ${ }^{13} \mathrm{C}$-sugars.

Pyrazine, 15.5 min

\begin{tabular}{l|r|r|r|r|c}
\hline Ions monitored, $\mathrm{m} / \mathrm{z}$ & 80 & 81 & 82 & 83 & 84 \\
\hline Glucose, natural & 100.00 & $\mathrm{ND}$ & $\mathrm{ND}$ & $\mathrm{ND}$ & $\mathrm{ND}$ \\
$\mathrm{U}{ }^{13} \mathrm{C}$ Glucose & 88.12 & $\mathrm{ND}$ & 11.88 & $\mathrm{ND}$ & $\mathrm{ND}$ \\
& & & & & \\
Fructose, natural & 90.39 & 9.61 & $\mathrm{ND}$ & $\mathrm{ND}$ & $\mathrm{ND}$ \\
$\mathrm{U}{ }^{13} \mathrm{C}$ Fructose & 91.10 & $\mathrm{ND}$ & 8.90 & $\mathrm{ND}$ & $\mathrm{ND}$ \\
${ }^{13} \mathrm{C}_{1}$ Fructose & 89.56 & 10.44 & $\mathrm{ND}$ & $\mathrm{ND}$ & $\mathrm{ND}$ \\
${ }^{13} \mathrm{C}_{2}$ Fructose & 92.94 & 7.06 & $\mathrm{ND}$ & $\mathrm{ND}$ & $\mathrm{ND}$
\end{tabular}

Methylpyrazine, $22.7 \mathrm{~min}$

\begin{tabular}{l|r|r|r|r|r|r}
\hline Ions monitored, $\mathrm{m} / \mathbf{z}$ & 94 & 95 & 96 & 97 & 99 & \\
\hline Glucose, natural & 99.73 & $\mathrm{ND}$ & $\mathrm{ND}$ & 0.27 & $\mathrm{ND}$ & \\
$\mathrm{U}{ }^{13} \mathrm{C}$ Glucose & 88.42 & $\mathrm{ND}$ & 7.37 & 4.21 & $\mathrm{ND}$ \\
& & & & & & \\
& 91.92 & 7.66 & 0.25 & 0.17 & $\mathrm{ND}$ \\
Fructose, natural & 85.00 & $\mathrm{ND}$ & 6.00 & 8.32 & 0.67 \\
$\mathrm{U}^{13} \mathrm{C}$ Fructose & 86.23 & 13.04 & 0.59 & 0.15 & $\mathrm{ND}$ \\
${ }^{13} \mathrm{C}_{1}$ Fructose & 88.52 & 10.56 & 0.92 & $\mathrm{ND}$ & $\mathrm{ND}$ \\
${ }^{13} \mathrm{C}_{2}$ Fructose & & & & & \\
\hline
\end{tabular}

2,6-Dimethylpyrazine, $27.3 \mathrm{~min}$

\begin{tabular}{|c|c|c|c|c|c|}
\hline lons monitored, $\mathrm{m} / \mathrm{z}$ & 108 & 109 & 110 & 111 & 114 \\
\hline Glucose, natural & 99.46 & ND & ND & 0.54 & ND \\
\hline $\mathrm{U}^{13} \mathrm{C}$ Glucose & 87.67 & ND & ND & 12.33 & ND \\
\hline Fructose, natural & 91.40 & 7.52 & 0.78 & 0.30 & ND \\
\hline $\mathrm{U}^{13} \mathrm{C}$ Fructose & 87.27 & ND & ND & 12.06 & 0.67 \\
\hline${ }^{13} \mathrm{C}_{1}$ Fructose & 84.04 & 14.16 & 1.34 & 0.46 & ND \\
\hline${ }^{13} \mathrm{C}_{2}$ Fructose & 83.97 & 15.10 & 0.93 & ND & ND \\
\hline
\end{tabular}

Ethylpyrazine, $27.5 \mathrm{~min}$

\begin{tabular}{|c|c|c|c|c|c|c|c|c|}
\hline Ions monitored, $\mathrm{m} / \mathrm{z}$ & 107 & 108 & 109 & 110 & 111 & 112 & 113 & 114 \\
\hline Glucose, natural & 59.02 & 38.35 & 2.63 & ND & ND & ND & ND & ND \\
\hline $\mathrm{U}^{13} \mathrm{C}$ Glucose & 52.37 & 35.73 & 6.52 & 2.84 & 2.18 & 0.35 & ND & ND \\
\hline Fructose, natural & 60.08 & 37.39 & 2.53 & ND & ND & ND & ND & ND \\
\hline $\mathrm{U}^{13} \mathrm{C}$ Fructose & 53.92 & 34.39 & 5.88 & 1.87 & 2.38 & 1.03 & 0.52 & ND \\
\hline${ }^{13} \mathrm{C}_{1}$ Fructose & 55.26 & 40.04 & 4.51 & 0.19 & ND & ND & ND & ND \\
\hline${ }^{13} \mathrm{C}_{2}$ Fructose & 59.58 & 36.28 & 4.14 & ND & ND & ND & ND & ND \\
\hline
\end{tabular}


Table 5 (contd).

2,3-Dimethylpyrazine, $27.7 \mathrm{~min}$

\begin{tabular}{l|r|r|r|r|r|r|r}
\hline Ions monitored, $\mathrm{m} / \mathrm{z}$ & 108 & 109 & 110 & 111 & 112 & 114 & \\
\hline Glucose, natural & 98.38 & $\mathrm{ND}$ & $\mathrm{ND}$ & $\mathrm{ND}$ & 1.62 & $\mathrm{ND}$ \\
$\mathrm{U}{ }^{13} \mathrm{C}$ Glucose & 87.23 & $\mathrm{ND}$ & 5.55 & $\mathrm{ND}$ & 4.89 & 2.32 \\
& & & & & & & \\
& 89.21 & 7.55 & $\mathrm{ND}$ & $\mathrm{ND}$ & 3.24 & $\mathrm{ND}$ \\
Fructose, natural & 87.29 & $\mathrm{ND}$ & 8.72 & $\mathrm{ND}$ & 4.00 & $\mathrm{ND}$ \\
$\mathrm{U}{ }^{13} \mathrm{C}$ Fructose & 76.91 & 17.69 & 1.47 & $\mathrm{ND}$ & 3.93 & $\mathrm{ND}$ \\
${ }^{13} \mathrm{C}_{1}$ Fructose & 83.48 & 12.06 & $\mathrm{ND}$ & 2.22 & 2.25 & $\mathrm{ND}$
\end{tabular}

2-Ethyl-6-methylpyrazine, $30.8 \mathrm{~min}$

\begin{tabular}{l|r|r|r|r|r|r|r|r|r}
\hline Ions monitored, $\mathrm{m} / \mathbf{z}$ & 121 & 122 & 123 & 124 & 125 & 126 & 128 & 129 & \\
\hline Glucose, natural & 64.54 & 34.59 & $\mathrm{ND}$ & $\mathrm{ND}$ & 0.87 & $\mathrm{ND}$ & $\mathrm{ND}$ & $\mathrm{ND}$ \\
$\mathrm{U}{ }^{13} \mathrm{C}$ Glucose & 59.90 & 32.37 & $\mathrm{ND}$ & 4.70 & 2.57 & 0.47 & $\mathrm{ND}$ & $\mathrm{ND}$ \\
& & & & & & & & & $\mathrm{ND}$ \\
$\mathrm{Fructose}$, natural & 63.03 & 32.98 & 3.10 & 0.30 & 0.59 & $\mathrm{ND}$ & $\mathrm{ND}$ & $\mathrm{ND}$ \\
$\mathrm{U}{ }^{13} \mathrm{C}$ Fructose & 56.90 & 33.26 & 0.00 & 5.05 & 4.18 & 0.62 & $\mathrm{ND}$ & $\mathrm{ND}$ & $\mathrm{ND}$ \\
${ }^{13} \mathrm{C}_{1}$ Fructose & 55.58 & 35.75 & 7.77 & 0.44 & 0.46 & $\mathrm{ND}$ & $\mathrm{ND}$ & $\mathrm{ND}$ \\
${ }^{13} \mathrm{C}_{2}$ Fructose & 58.50 & 36.40 & 4.34 & $\mathrm{ND}$ & 0.76 & $\mathrm{ND}$ & $\mathrm{ND}$ & $\mathrm{ND}$
\end{tabular}

2-Ethyl-5-methylpyrazine, $31 \mathrm{~min}$

\begin{tabular}{l|r|r|r|r|r|r|r|r}
\hline lons monitored, $\mathrm{m} / \mathrm{z}$ & 121 & 122 & 123 & 124 & 125 & 126 & 128 & 129 \\
\hline $\begin{array}{l}\text { Glucose, natural } \\
\mathrm{U}{ }^{13} \mathrm{C} \text { Glucose }\end{array}$ & 48.34 & 51.18 & $\mathrm{ND}$ & 0.48 & $\mathrm{ND}$ & $\mathrm{ND}$ & $\mathrm{ND}$ & $\mathrm{ND}$ \\
& 52.78 & 38.55 & $\mathrm{ND}$ & 4.65 & 3.20 & 0.46 & 0.36 & $\mathrm{ND}$ \\
Fructose, natural & & & & & & & & \\
$\mathrm{U}{ }^{13} \mathrm{C}$ Fructose & 48.47 & 47.17 & 4.10 & 0.26 & $\mathrm{ND}$ & $\mathrm{ND}$ & $\mathrm{ND}$ & $\mathrm{ND}$ \\
${ }^{13} \mathrm{C}_{1}$ Fructose & 48.99 & 41.31 & $\mathrm{ND}$ & 4.17 & 4.88 & 0.65 & $\mathrm{ND}$ & $\mathrm{ND}$ \\
${ }^{13} \mathrm{C}_{2}$ Fructose & 47.10 & 43.77 & 8.12 & 1.01 & $\mathrm{ND}$ & $\mathrm{ND}$ & $\mathrm{ND}$ & $\mathrm{ND}$ \\
& 46.56 & 46.69 & 6.13 & 0.62 & $\mathrm{ND}$ & $\mathrm{ND}$ & $\mathrm{ND}$ & $\mathrm{ND}$
\end{tabular}

2-Ethyl-3,6-dimethylpyrazine, $33.5 \mathrm{~min}$

\begin{tabular}{l|r|r|r|r|r|r|r|r|r|r}
\hline Ions monitored, $\mathbf{m} / \mathbf{z}$ & 135 & 136 & 137 & 138 & 139 & 140 & 141 & 143 & 144 \\
\hline Glucose, natural & 62.69 & 37.31 & ND & ND & ND & ND & ND & ND & ND \\
U ${ }^{13}$ C Glucose & 55.26 & 37.35 & ND & 2.68 & 3.48 & 1.23 & ND & ND & ND & \\
& & & & & & & & & & ND \\
Fructose, natural & 47.07 & 40.75 & 8.94 & 3.24 & ND & ND & ND & ND & ND \\
$\mathrm{U}^{13}$ C Fructose & 42.53 & 40.83 & ND & 8.60 & 8.04 & ND & ND & ND & ND \\
${ }^{13} \mathrm{C}_{1}$ Fructose & 48.89 & 42.44 & 8.67 & ND & ND & ND & ND & ND & ND & ND \\
${ }^{13} \mathrm{C}_{2}$ Fructose & 49.72 & 37.05 & 13.23 & ND & ND & ND & ND & ND & ND \\
& & & & & & & & &
\end{tabular}

$\mathrm{Nd}^{*}=$ Not detected 
Table 6.

Percent ion abundances in ketones/furans from microwave heat treated tobacco dust suspensions with ${ }^{13}$ C-sugars.

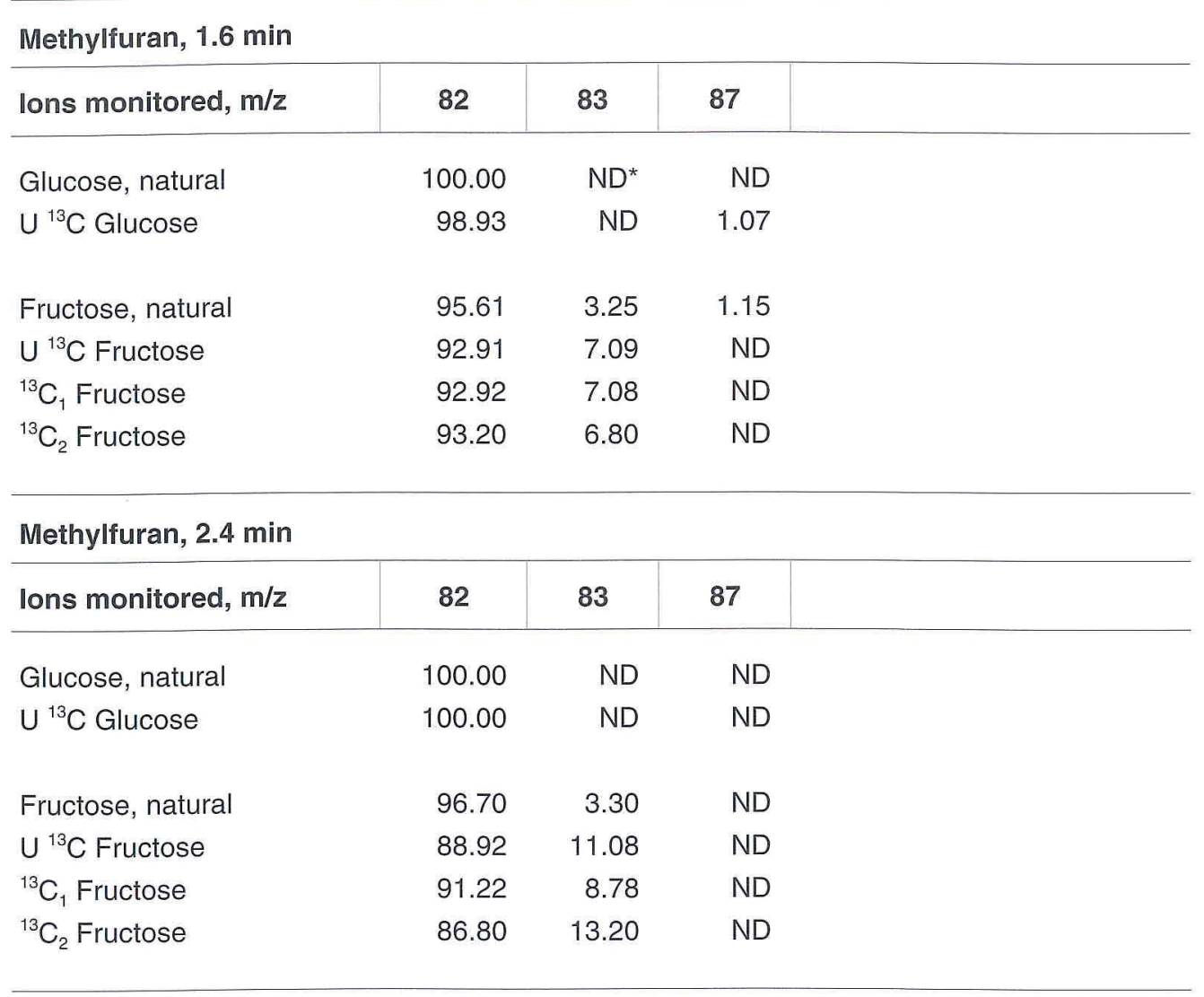

2-Butanone, $4.5 \mathrm{~min}$

\begin{tabular}{l|r|r|r|r}
\hline lons monitored, $\mathrm{m} / \mathbf{z}$ & \multicolumn{1}{|c|}{72} & \multicolumn{1}{c}{73} & \multicolumn{1}{c}{76} & \\
\hline Glucose, natural & 100.00 & $\mathrm{ND}$ & $\mathrm{ND}$ & \\
$\mathrm{U}{ }^{13} \mathrm{C}$ Glucose & 97.69 & $\mathrm{ND}$ & 2.31 & \\
& & & & \\
& 96.55 & 3.45 & $\mathrm{ND}$ \\
Fructose, natural & 93.96 & 5.27 & 0.77 \\
$\mathrm{U}{ }^{13} \mathrm{C}$ Fructose & 93.29 & 6.71 & $\mathrm{ND}$ \\
${ }^{13} \mathrm{C}_{1}$ Fructose & 94.77 & 5.23 & $\mathrm{ND}$ \\
${ }^{13} \mathrm{C}_{2}$ Fructose & & & \\
\hline
\end{tabular}

\section{2,3-Butandione, $5.0 \mathrm{~min}$}

\begin{tabular}{|c|c|c|c|}
\hline lons monitored, $\mathrm{m} / \mathrm{z}$ & 86 & 87 & 90 \\
\hline Glucose, natural & 100.00 & ND & ND \\
\hline $\mathrm{U}^{13} \mathrm{C}$ Glucose & 99.06 & ND & 0.94 \\
\hline Fructose, natural & 95.20 & 4.80 & ND \\
\hline $\mathrm{U}^{13} \mathrm{C}$ Fructose & 94.37 & 5.20 & 0.42 \\
\hline${ }^{13} \mathrm{C}_{1}$ Fructose & 93.50 & 6.50 & ND \\
\hline${ }^{13} \mathrm{C}_{2}$ Fructose & 93.23 & 6.77 & ND \\
\hline
\end{tabular}


Table 6 (contd).

\section{2,3-Pentandione, $13.5 \mathrm{~min}$}

\begin{tabular}{l|r|r|r|}
\hline Ions monitored, $\mathrm{m} / \mathrm{z}$ & 100 & 101 & 105 \\
\hline Glucose, natural & 100.00 & $\mathrm{ND}$ & $\mathrm{ND}$ \\
$\mathrm{U}{ }^{13} \mathrm{C}$ Glucose & 97.94 & $\mathrm{ND}$ & 2.06 \\
& & & \\
Fructose, natural & 93.06 & 6.94 & $\mathrm{ND}$ \\
$\mathrm{U}{ }^{13} \mathrm{C}$ Fructose & 91.96 & 5.47 & 2.57 \\
${ }^{13} \mathrm{C}_{1}$ Fructose & 90.14 & 9.86 & $\mathrm{ND}$ \\
${ }^{13} \mathrm{C}_{2}$ Fructose & 92.34 & 7.66 & $\mathrm{ND}$ \\
& & & \\
\hline
\end{tabular}

\section{Furfural, $26.4 \mathrm{~min}$}

\begin{tabular}{l|c|c|c|c|c|c}
\hline Ions monitored, $\mathrm{m} / \mathbf{z}$ & 95 & 96 & 97 & 100 & 101 & \\
\hline Glucose, natural & 49.36 & 50.60 & $\mathrm{ND}$ & 0.04 & $\mathrm{ND}$ \\
$\mathrm{U}{ }^{13} \mathrm{C}$ Glucose & 48.11 & 49.30 & $\mathrm{ND}$ & 1.38 & 1.21 \\
& & & & & \\
Fructose, natural & 48.10 & 49.15 & 2.75 & $\mathrm{ND}$ & $\mathrm{ND}$ \\
$\cup{ }^{13} \mathrm{C}$ Fructose & 47.80 & 47.03 & 2.96 & 1.16 & 1.04 \\
${ }^{13} \mathrm{C}_{1}$ Fructose & 47.44 & 49.15 & 3.41 & $\mathrm{ND}$ & $\mathrm{ND}$ \\
${ }^{13} \mathrm{C}_{2}$ Fructose & 48.08 & 48.08 & 3.84 & $\mathrm{ND}$ & $\mathrm{ND}$ \\
& & & & & \\
\hline
\end{tabular}

Acetylfurfural, $29.5 \mathrm{~min}$

\begin{tabular}{l|c|c|r|r|r|r}
\hline lons monitored, $\mathrm{m} / \mathrm{z}$ & 95 & 96 & 101 & 110 & 111 & 116 \\
\hline Glucose, natural & 67.53 & $\mathrm{ND}$ & 0.15 & 32.32 & $\mathrm{ND}$ & $\mathrm{ND}$ \\
$\mathrm{U}{ }^{13} \mathrm{C}$ Glucose & 69.40 & $\mathrm{ND}$ & $\mathrm{ND}$ & 30.29 & $\mathrm{ND}$ & 0.31 \\
& & & & & & \\
Fructose, natural & 61.48 & 5.74 & $\mathrm{ND}$ & 31.40 & 1.39 & $\mathrm{ND}$ \\
$\mathrm{U}{ }^{13} \mathrm{C}$ Fructose & 67.00 & 4.80 & $\mathrm{ND}$ & 24.79 & 3.04 & 0.36 \\
${ }^{13} \mathrm{C}_{1}$ Fructose & 63.73 & 6.12 & $\mathrm{ND}$ & 26.92 & 3.22 & $\mathrm{ND}$ \\
${ }^{13} \mathrm{C}_{2}$ Fructose & 65.38 & 5.60 & $\mathrm{ND}$ & 25.96 & 3.06 & $\mathrm{ND}$ \\
& & & & & & \\
\hline
\end{tabular}

5-Methylfurfural, $32.2 \mathrm{~min}$

\begin{tabular}{|c|c|c|c|c|c|}
\hline lons monitored, $\mathrm{m} / \mathrm{z}$ & 109 & 110 & 111 & 115 & 116 \\
\hline Glucose, natural & 48.50 & 51.48 & ND & 0.02 & ND \\
\hline $\mathrm{U}^{13} \mathrm{C}$ Glucose & 47.24 & 52.23 & ND & 0.28 & 0.25 \\
\hline Fructose, natural & 46.54 & 50.07 & 3.39 & ND & ND \\
\hline $\mathrm{U}^{13} \mathrm{C}$ Fructose & 45.38 & 50.84 & 3.49 & 0.16 & 0.13 \\
\hline${ }^{13} \mathrm{C}_{1}$ Fructose & 46.25 & 50.03 & 3.73 & ND & ND \\
\hline${ }^{13} \mathrm{C}_{2}$ Fructose & 46.64 & 49.37 & 3.99 & ND & ND \\
\hline
\end{tabular}

$\mathrm{Nd}^{*}=$ Not detected 
sugars. The findings documented here demonstrate for the first time pathways associated with the production of volatile materials in heat treated tobacco suspensions.

\section{REFERENCES}

1. Mauron, J.: The Maillard reaction in food; a critical review from the nutritional standpoint; Prog. Fd. Nutr. Sci. 5 (1981) 5.

2. Hodge, J.E.: Chemistry of browning reactions in model systems; J. Agric. Food Chem. 1 (1953) 928.

3. Arnoldi A., C. Arnoldi, O. Baldi, and A. Griffini: Strecker degradation of leucine and valine in lipidic model systems; J. Agric. Food Chem. 35 (1987) 1035.

4. Stewart T.F.: Survey of the chemistry of amino acidreducing sugar reactions in relation to aroma production; The British Food Manufacturing Industries Research Association, Scientific and Technical Surveys, Number 61, 1969, p 23.

5. Pons, I., C. Garrault, J.-N. Jaubert and J. Morel: Analysis of aromatic caramel; Food Chem. 39 (1991) 311.

6. Fors, S.: Sensory properties of volatile Maillard reaction products and related compounds; in: The Maillard reaction in foods and nutrition; American Chemical Society Symposium Series, No. 215, edited by G.R. Waller and M.S. Feather, ACS, Washington, D.C., 1983, pp 185-286.

7. Coleman, III, W.M.: Automated purge and trap gas chromatography analysis of headspace volatiles from natural products; J Chrom. Sci. 30 (1992) 159.

8. Coleman, III, W.M., J.L. White and T.A. Perfetti: Characteristics of heat-treated aqueous extracts of peanuts and cashews; J. Agric Food Chem. 42 (1994) 190.

9. Coleman, III, W.M., J.L. White and T.A. Perfetti: A hyphenated GC-based quantitative analysis of volatile materials from natural products; J. Chrom. Sci. 32 (1994) 323.

10. Coleman, III, W.M., J.L. White and T.A. Perfetti: Investigation of a unique commonality from a wide range of natural materials as viewed from the Maillard reaction perspective; J. Sci. Food Agric. 70 (1996) 405.

11. Coleman, III, W.M.: A chromatographic study of the influence of ion concentrations and $\mathrm{pH}$ on the yield of volatile materials from heat-treated natural product extracts; J. Chrom. Sci. 34 (1996) 1.

12. Coleman, III, W.M., L.D. Stafford and T.A. Perfetti: Amino acids and their role in the production of volatile materials in heat-treated tobacco; Tobacco Chemists' Research Conference, September 14-17, 1997, Winston Salem, USA.
13. Arnoldi A., C. Arnoldi, O. Baldi and A. Griffini: Flavor components in the Maillard reaction of different amino acids with fructose in cocoa butterwater; J. Agric. Food Chem. 36 (1988) 988.

14. Coleman, W.M., III: Unpublished findings. Addition of leucine and isoleucine to tobacco dust suspensions followed by heat treatment produced increases in the amounts of 3 and 2-methylbutanal, respectively.

15. Parliment, T.H., M.J. Morello, and R.J. McGorrin: Thermally generated flavors, Maillard, microwave and extrusion processes; American Chemical Society Symposium Series, No. 543, ACS, Washington, DC, 1994.

16. Giguere, R.J., T.L. Bray, and S.M. Duncan: Application of commercial microwave ovens to organic synthesis; Tetrahedron Lett. 27 (1986) 4945.

17. Gedye R.N., F.E. Smith, and K.C. Westway: The rapid synthesis of organic compounds in microwave ovens; Can. J. Chem. 66 (1988) 17.

18. Strauss, C.R., and R.W. Trainor: Application of new microwave reactors for food and research; in: Biotechnology for improved food and flavors, American Chemical Society Symposium Series, No. 637, edited by G.R. Takeoka, R. Teranishi, P.J. Williams, and A. Kobayashi, ACS, Washington, DC, 1996.

19. Koehler, P.E., and G.V. Odell: Factors affecting the formation of pyrazine compounds in sugar-amine reactions; J. Agric. Food Chem. 18 (1970) 895.

20. Mason M.E., J.A. Newell, B.R. Johnson, P.E. Koehler and G.R. Waller: Nonvolatile flavor components of peanuts; J. Agric. Food Chem. 17 (1969) 729.

21. Shibamoto, T., and R.A. Bernhard: Effect of time, temperature, and reactant ratio on pyrazine formation in model systems: J. Agric. Food Chem. 24 (1976) 847.

22. Shibamoto, T., and R.A. Bernhard: Investigation of pyrazine formation pathways in glucose-ammonia model systems; Agric. Biol. Chem. 41 (1977) 143.

23. Shibamoto T. and R. A. Bernhard: Investigation of pyrazine formation pathways in sugar-ammonia model systems; J. Agric. Food Chem. 25 (1977) 609.

24. Shibamoto T. and R. A. Bernhard: Formation of heterocyclic compounds from the reaction of $\mathrm{L}$ rhamnose with ammonia; J. Agric. Food Chem. 26 (1978) 183.

25. Keyhani A. and V. A. Yaylayan: Elucidation of the mechanism of pyrazinone formation in glycine model systems using labeled sugars and amino acids; J. Agric. Food Chem. 44 (1996) 2511.

26. Nyhammar, T., K. Olsson and P. A. Pernemalm: Strecker degradation products from $\left[1-{ }^{13} \mathrm{C}\right]$-D-glucose and glycine; in: The Maillard reaction in foods and nutrition, American Chemical Society Symposium 
Series, No. 215, edited by G.R. Waller and M.S. Feather, ACS, Washington, D.C., 1983, pp 71-82.

27. Tressel, R., E. Kersten, C. Nittka, and D. Rewicki: Mechanistic studies on the formation of pyrroles and pyridines from $\left[1-{ }^{13} \mathrm{C}\right]-\mathrm{D}$-Glucose and $\left[1-{ }^{13} \mathrm{C}\right]-\mathrm{S}$ arabinose; in: Maillard reactions in chemistry, food, and health. The Proceedings of the Fifth International Symposium on the Maillard Reaction, edited by T.P. Labuza, G.A. Reineccius, V. Monnier, J. O’Brien, and J. Baynes, 1993, pp 51-60.

28. Rewicki, D., R. Tressel, E. Kersten, and C. Nittka: Mechanistic studies on the formation of Maillard products from $\left[1-{ }^{13} \mathrm{C}\right]$-D-fructose, in: Maillard reactions in chemistry, food, and health. The Proceedings of the Fifth International Symposium on the Maillard Reaction, edited by T.P. Labuza, G.A. Reineccius, V. Monnier, J. O'Brien, and J. Baynes, 1993, pp 61-68.
29. Mabrouk, A.F.: Flavor of browning reaction products, in: Food taste chemistry, American Chemical Society Symposium Series, No. 115, edited by J.C. Boudreau; ACS, Washington, D.C., 1979, pp 205-245.

Address for correspondence:

W. M. Coleman, III, and T. A. Perfetti

R.J. Reynolds Tobacco Company

P. O. Box 1487

Winston-Salem, NC 27102-1487, USA. 